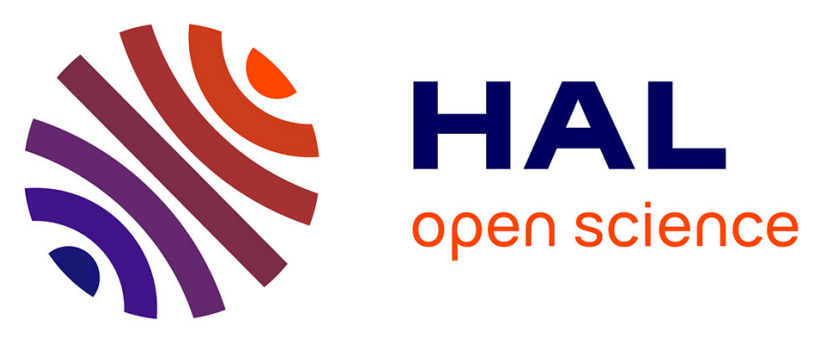

\title{
Landscape use and fruit cultivation in Petra (Jordan) from Early Nabataean to Byzantine times (2nd century $\mathrm{BC}-5$ th century AD) \\ C. Bouchaud, Christiane Jacquat, Danièle Martinoli
}

\section{- To cite this version:}

C. Bouchaud, Christiane Jacquat, Danièle Martinoli. Landscape use and fruit cultivation in Petra (Jordan) from Early Nabataean to Byzantine times (2nd century BC - 5th century AD). Vegetation History and Archaeobotany, 2017, 26 (2), pp.223-244. 10.1007/s00334-016-0582-y . hal-02306033

\section{HAL Id: hal-02306033 \\ https://hal.science/hal-02306033}

Submitted on 1 Oct 2020

HAL is a multi-disciplinary open access archive for the deposit and dissemination of scientific research documents, whether they are published or not. The documents may come from teaching and research institutions in France or abroad, or from public or private research centers.
L'archive ouverte pluridisciplinaire HAL, est destinée au dépôt et à la diffusion de documents scientifiques de niveau recherche, publiés ou non, émanant des établissements d'enseignement et de recherche français ou étrangers, des laboratoires publics ou privés. 


\title{
This is a post-peer-review, pre-copyedit version of an article published in Vegetation History and Archaeobotany. The final authenticated version is available online at: https://doi.org/10.1007/s00334-016-0582-y
}

\section{Landscape use and fruit cultivation in Petra (Jordan) from Early Nabataean to Byzantine times (2nd century BC - 5th century AD)}

\author{
Charlene Bouchaud ${ }^{1}$, Christiane JACQuat ${ }^{2}$, Daniele Martinoli ${ }^{3}$ \\ ${ }^{1}$ AASSP, UMR 7209, CNRS/MNHN, Sorbonne Universités, CP56, 55 rue Buffon, \\ 75005 Paris, France, e-mail: charlene.bouchaud@gmail.com \\ ${ }^{2}$ Department of Plant and Microbial Biology, University of Zürich, \\ Zollikerstrasse 107, 8008 Zürich, Switzerland \\ ${ }^{3}$ IPNA, University of Basel, Spalenring 145, 4055 Basel, Switzerland
}

\begin{abstract}
Archaeobotanical analyses of charred seeds, fruit and wood charcoal from the residential part of the ez-Zantur area at Petra, Jordan, provide new data on the agricultural economy and use of the landscape in this famous merchant Nabataean city from the middle of the 2nd century BC to the beginning of the 5th century AD. The study is based on analyses of 7,499 whole and fragmented seeds, pips and fruit stones and 624 charcoal fragments sampled from household deposits. The results show that the food supply was based on common Mediterranean cultivated taxa such as cereals (Hordeum vulgare, Triticum aestivum/durum), pulses (Lens culinaris) and fruit (Olea europaea, Ficus carica, Vitis vinifera), which were probably cultivated both in the city and its hinterland. The by-products from the processing of cereals and fruit trees played a significant role in fuel supply, supplementing woody wild plants obtained from rocky slopes and the desert valley. The variety of fuel resources shows a major capacity to manage complex supply networks and perhaps the rarity of natural woodland cover. The existence of orchards within the city centre and notably olive groves is indicated in the Early Nabataean period
\end{abstract}


(mid 2nd century to mid 1st century BC) but they expanded during the Classical Nabataean period (mid 1st century BC to 1st century AD), probably reflecting specialised fruit growing. Unusual plant remains such as Prunus armeniaca (apricot), P. persica (peach) and Juglans regia (walnut) are considered to be social indicators of prosperity. These archaeobotanical results fit with others from this region and match with the urbanization and social dynamics of the city of Petra.

Keywords Seed and fruit analysis $\cdot$ Wood charcoal analysis $\cdot$ Petra $\cdot$ Antiquity and Late Antiquity $\cdot$ Fruit growing $\cdot$ Fuel management

\section{Introduction}

One of the most complete descriptions of Petra, Jordan, is attributed to Strabo who reports the Athenodorus of Tarsus' account at the end of the 1st century BC: "The metropolis of the Nabataeans is Petra, as it is called; for it lies on a site which is otherwise smooth and level, but it is fortified all round by a rock, the outside parts of the site being precipitous and sheer, and the inside parts having springs in abundance, both for domestic purposes and for watering gardens." (Geographia XVI.4.21, Jones 1961) (Fig. 1). This sentence introduces two important aspects about Petra and its ancient inhabitants: the hilly character of the place due to the successions of sandstone and limestone rocks (Besançon 2010; Beckers et al. 2013) and the ability of the Nabataean tribes to manage their territory. However, while Petra is especially known for its role as a trading centre and its impressive architecture (Netzer 2003; McKenzie 2005), the daily life and relationships of the occupants with their environment remain poorly understood. More specifically, the role of crop growing within the city itself has rarely been examined, especially given the lack of material evidence and analyses. Issues relating to agricultural economy and landscape management have mainly been addressed through archaeological surveys and the study of the water management systems (Oleson 1995; Lavento et al. 2004, 2007; Al-Salameen 2005; Bellwald 2006; Kouki 2009, 2012, 2013; Knodell and Alcock 2011; Tholbecq 2013) or geographical approaches (Gentelle 2009; Besançon 2010). Bioarchaeological studies remain limited (Studer 2002, 2007; Studer and Schneider 2008; Tholbecq et al. 2008; Ramsay and Bedal 2015). Our study aims to understand new economic and territorial aspects of Petra by focusing on charred plant remains (fruits, seeds and wood) found in the ez-Zantur area. Ez-Zantur was a residential 
quarter located in the city centre, which consisted of several buildings and domestic facilities that were occupied from at least the mid 2 nd century $\mathrm{BC}$ to the beginning of the 5th century AD (Fig. 1). The excavations were conducted from 1988 to 2001 by the Classical Archaeology Department of the University of Basel and directed by R. A. Stucky and B. Kolb under the authority of the SwissLiechtenstein Foundation for Archaeological Research Abroad (Bignasca et al. 1996; Schmid and Kolb 2000; Grawehr and Keller 2006). The ez-Zantur excavation has provided the most important discoveries on the domestic and residential lifestyles in Petra to date. Archaeobotanical analyses conducted in this area provide new data on farming and use of the landscape in and around the city from the mid 2nd century BC to the early 5 th century AD and offer new insights about how the Petra inhabitants supplied themselves with food and fuel in such a craggy and arid landscape.

\section{Regional setting, vegetation and chronology of Petra}

\section{Geographical setting}

The Petra region, Ma'an Governerate, Jordan, is located between the arid plains of wadi Arabah and the desert steppes of the Transjordanian plateau, in the mountainous region of Edom. The very large site of Petra is composed of a succession of granites and metamorphic bedrock, Palaeozoic sandstone formations dissected by deep gorges and canyons between about $600-1,100 \mathrm{~m}$ a.s.1. and Cretaceous limestone above 1,100 m a.s.1. (Fig. 2; Beckers et al. 2013). Climatic conditions of the southern Levant have generally remained unchanged since the mid Holocene (Rambeau 2010; Finné et al. 2011). Rainfall is irregular and mainly occurs during winter. Eastern summits such as jabal Shara have the highest precipitation, 350 to $400 \mathrm{~mm} /$ year. At the altitude of the centre of Petra, 860-940 $\mathrm{m}$ a.s.1., annual rainfall reaches $150-200 \mathrm{~mm}$ and the mean annual temperature is about $15^{\circ} \mathrm{C}$. Arid conditions, with very low rainfall $(50 \mathrm{~mm} /$ year) and high mean annual temperature $\left(25^{\circ} \mathrm{C}\right)$ prevail over the lowlands of the wadi Arabah. As a result, the region is characterized by heterogeneous landscapes, and the transition from the semi-arid zone with wooded Mediterranean steppes to arid desert occurs over less than $40 \mathrm{~km}$ east to west, offering large plant diversity, 
although the modern landscape has been considerably affected by human activity and climatic erosion processes (Lücke 2008). Sporadic Quercus ithaburensis and Q. calliprinos (deciduous and evergreen oaks), together with Pistacia atlantica and P. palaestina (pistachios) are evidence of a more widespread Mediterranean woodland above $1,200 \mathrm{~m}$ in the past. The lower levels have scattered Juniperus phoenicea (Phoenician juniper) and shrubby plants, mainly Retama raetam and Thymelaea hirsuta. Sudanian and Sahara-Arabian vegetation, characterized by desert bush vegetation and scattered Acacia tortilis ssp. tortilis, A. tortilis ssp. raddiana (acacias) and Tamarix aphylla, T. negevensis and T. palaestina (tamarisks), occur in the lowlands (Ruben 2006; Hunt et al. 2007; Besançon 2010; Beckers et al. 2013).

\section{Agricultural potential}

The hilly and dry conditions around Petra made farming quite difficult. The soils are mostly shallow and poor in nutrients. Red Mediterranean soils, terra rossa, on limestone bedrocks are sporadically present on the highest summits, as seen on jabal ash-Shara, but torrential rains are frequent and slope run-off leaves no time for slow absorption into the soil, making it a major form of erosion. The lower exposures of the median sandstone plateau have some sandy alluvium deposits favourable to agriculture in spite of the relatively limited usable area and lower precipitation. There are also larger flat areas outside the centre of Petra, towards jebel Haroun and Beidha (Gentelle 2009; Besançon 2010). The mean annual rainfall is barely sufficient for the dry farming of cereals, but the cultivation of more demanding plants would require manuring and sometimes irrigation. Today, the rocky outcrop, now mostly dedicated to tourist activities, is used for sporadic dry cultivation of Hordeum vulgare (barley) and Lens culinaris (lentil) and a few irrigated fruit groves are found along the seasonal streams (Simms and Russell 1997; Besançon 2010; Kouki 2012, pp 103-104).

\section{Occupation chronology in Petra and ez-Zantur}

\section{The first Nabataean occupations (4th - mid 1st century BC)}

Mainly known for its Nabataean inhabitants, the prehistory of the Petra region is however much older, principally known from Pre-pottery Neolithic (Byrd 2005), 
Neolithic (Gebel et al. 1997; Gebel and Hermansen 2004) and Iron Age settlements (Bienkowski 1990, 2013). The first known reference to the Nabataeans was made by Diodorus Siculus referring to the Greek expedition to Petra in 312-311 BC (Bibliotheca Historica XIX.94.100, Geer 1947). At this time, Petra began to play an important role in trade relationships in the southern Near East and became the major Nabataean centre (Wenning 2007). The Arab tribes living there are described as nomadic sheep and camel herders, forbidden to cultivate land or build under penalty of death (Diodorus Siculus, B.H. XIX.94.23 ). This account most probably follows the literary tradition of the depiction of nomads in antiquity (Graf 1990). Indeed, there is corresponding archaeological evidence of semi-permanent and permanent occupations, especially those corresponding to small structures dated to the 4th-3rd century BC found below the area of the later Qasr al-Bint in the centre of Petra (Renel et al. 2012; Graf 2013; Renel and Mouton 2013), and then during the mid 2nd to mid 1st century BC at ez-Zantur (Stucky 1995) and to the east of jabal Numayr at the so-called Obodas Chapel (Tholbecq and Durand 2013). Distinctive Nabataean coins and pottery types were developed in the late 2nd to early 1st century BC (Schmid 2000, 2001, pp 368, 371-373). It is now accepted that while Nabataeans were largely involved in trade, part of the population was responsible for farming to provide food for the community (Fiema 1996; Kouki 2013; Tholbecq 2013). The oldest archaeological evidence of agricultural activities linked with Nabataean occupation recognized to date are a crusher structure discovered in a late 2 nd - early 1 st century BC layer in the ez-Zantur area, probably linked with oil extraction (Kolb and Keller 2001) and small and isolated contemporary farmsteads in the surroundings of Petra (Kouki 2012, p 110).

\section{Classical Nabataean (mid 1st century BC to 1st century AD)}

According to the classical writers, Petra was considered a royal city by the mid1st century BC by Flavius Josephus in Jewish Antiquities XIV.5.1 and The Jewish War I.2 [125](Marcus 1966; Thackeray 1967; Fiema and Schmid 2016). The city grew during the second half of the 1st century BC and the 1st century AD. Temples, market places, private houses, pavements and luxurious facilities such as gardens and pools were built in the city centre, while rock-built tombs and places for worship developed in and around it (Schmid 2001; McKenzie 2005; 
Graf 2007; Bedal 2013, Fiema and Schmid 2016). Cisterns and subterranean channels $6-8 \mathrm{~km}$ long carried water from the nearest springs to the city centre and a series of holding dams was built in order to manage the flash floods which occur in winter (Al-Muheisen 1990, 2009; Oleson 1995; Bellwald 2006). Nabataean houses of various sizes and qualities, supplied with fresh water via an aqueduct system, were erected on the ez-Zantur terraces (Bignasca et al. 1996; Kolb 2007). In the surroundings of Petra, rural settlements and run-off terrace systems came into existence, as well as olive and wine presses (Lavento et al. 2007; Gentelle 2009; Kouki 2009; Beckers et al. 2013; Tholbecq 2013). The faunal data in Petra are currently available mostly for the 1 st century AD and later. They show an economy similar to that of other contemporary Near Eastern settlements, based on sheep and goat herding supplemented by other domestic animals, notably camel and pig, very few hunted animals, as well as fish (Studer 2007).

\section{Roman, Late Roman and Byzantine occupations (2nd to 7th century $A D$ )}

The annexation of the Nabataean kingdom by Rome took place in AD 106. Petra remained an urban centre until the major trade routes moved to the east and south in the 4th century AD (Fiema 2002, 2003). Wealthy houses are recognized at ezZantur (Kolb and Keller 2001; Kolb 2003). The severe regional earthquake of AD 363 caused a decline in the occupation of the city centre (Fiema 2002, 2003;

Fiema and Schmid 2016). Some domestic rooms at ez-Zantur were destroyed and then re-built and used again during the Byzantine period until there was another earthquake that may have taken place in AD 419 (Bignasca et al. 1996). During the 5th and 6th centuries, the Byzantine city was a Christian religious centre and both carbonized Petra papyri (Frösen et al. 2002; Arjava et al. 2007; Arjava et al. 2011; Nasarat et al. 2012; Koenen et al. 2013) and survey studies (Kouki 2009; Knodell and Alcock 2011; Tholbecq 2013) underline the importance of agricultural production. A probably gradual urban decay into rural settlements happened from the 7 th century until the rediscovery of the city in the 19th century (Fiema 2002). 


\section{Materials and methods}

The present study is based on the plant material collected during the various excavation campaigns carried out in the ez-Zantur area between 1991 and 2002. It compiles data by various scholars from unpublished theses and dissertations (Martinoli 1997; Bouchaud 2011) and partially published works (Bouchaud 2015; Karg 1996; Jacquat and Martinoli 1999).

\section{Sampling and identification processes}

The soil samples came from four different excavation sectors corresponding to the three natural terraces of ez-Zantur (Ez I, III and IV) and one deep sounding (Ez II) (Fig. 1), dated to the Early Nabataean (mid 2nd to mid 1st century BC), Classical Nabataean (mid 1st century BC to 1 st century AD), Roman (2nd to 3rd century $\mathrm{AD})$, Late Roman (1st half of the 4th century) and Byzantine (early 5th century). Although the Early Nabataean period runs through the 4th century to the mid 1st century $\mathrm{BC}$, the ez-Zantur samples only contain material dated to the mid 2 nd to mid 1st century BC. Likewise, the Byzantine period, from the mid 4th century to the 6 th century $\mathrm{AD}$, is only represented here by samples from the early 5 th century AD.

The archaeological layers provided 80 samples from household sediment accumulations representing dumps, pit fills, soil layers, oven fills or ashy layers, where charred material was more likely to be found. The samples all corresponded to a mixture of primary and secondary deposits; no strict primary deposit was found. The preserved plant remains are thus very meaningful for archaeoethnobotanical interpretation (d'Alpoim Guedes and Spengler 2015). The selection process of the archaeological samples was initially planned for plant macro-remain (carpological) studies and no dispersed contexts suitable for archaeoenvironmental reconstruction through charcoal analyses were sampled (Théry-Parisot et al. 2010). The sediment samples were processed by wet sieving using 6,2 and $0.5 \mathrm{~mm}$ mesh sieves. When necessary, the $0.5 \mathrm{~mm}$ sieve residues were processed by flotation if there was a significant amount of carbonized material. The heavy fraction $(6 \mathrm{~mm})$ was sorted by eye to extract the wood charcoal fragments. The light fractions $(2$ and $0.5 \mathrm{~mm})$ were sorted under a stereoscopic microscope at $10 \times$ to $40 \times$ magnification to extract small wood 
charcoal fragments (only in the $2 \mathrm{~mm}$ fraction) and carpological remains consisting of seeds, fruits, chaff and other non-woody elements as well as nonplant remains such as dung fragments and micro-fauna. Of these, 62 samples, corresponding to 742.8 litres of sediment, contained carpological remains and 34 samples, corresponding to 275.1 litres of sediment, contained wood charcoal fragments (Table 1).

Fruits, seeds and other non-woody plant remains were identified under a stereoscopic microscope using up to $60 \times$ magnification. They were compared to illustrations in reference seed atlases (Berggren 1969, 1981; Anderberg 1994; Cappers et al. 2012) and to modern reference collections in the archaeobotanical laboratories at the Universities of Basel and Zürich and at the Museum National d'Histoire Naturelle in Paris.

Wood charcoal fragments were identified using a reflected-light microscope at $50 \times$ to $500 \times$ magnification. Archaeological specimens were compared to charcoal reference atlases (Fahn et al. 1986; Schweingruber 1990; Neumann et al. 2001) and to the modern reference collection at the Museum National d'Histoire Naturelle, Paris.

\section{Quantification methods}

The carpological analysis is based on the total number of remains, comprising whole and fragmented elements (Table 2), and the minimum number of items (MNI, Table 3) (Jones 1991; Marston 2015). For the latter, according to the fragmentation profiles from one sample to another, we consider that four fragments of Olea europaea (olive) endocarps, Phoenix dactylifera (date palm) fruit stones or Vitis vinifera (grape) pips represent one whole item. Although this method does not take into account the reality of each sample, it has the advantage of being easy to calculate and repeatable from one sample to another. Moreover, the remains of rachis fragments were converted into the equivalent number of caryopses; for a rachis segment of Hordeum vulgare able to bear one to three caryopses depending on sub-species (2 row, H. vulgare ssp. distichon or 6 row, $H$. vulgare ssp. vulgare), the number of remains is multiplied by two. For a segment of free-threshing wheat rachis (Triticum aestivum ssp. aestivum, bread wheat, or T. turgidum ssp. durum, hard wheat) having on average three caryopses, the number of segments is multiplied by three. A rachis segment of T. turgidum ssp. 
dicoccon (emmer) is multiplied by two (Cappers and Neef 2012, p 388). The caryopses of Triticum sp. are proportionally distributed among the free-threshing wheat and the emmer caryopses. Unidentified cereal rachis fragments are arbitrarily multiplied by two. Cereal bracts, culm node and root culm fragments are excluded, since these elements would provide redundant quantitative information with respect to caryopses and rachis remains. Finally, the minimum number of items (MNI) per sample is weighted by the sample volume collected (Table 3, Figs. 3, 4). Relative abundance (NR/total number of remains or $\mathrm{NMI} /$ total minimum number of remains) and ubiquity proportion (number of samples where the taxa is present/total number of samples) are used to discuss the results. Furthermore, the significance of the association between the contemporary terraces or between the different periods and the cultivated groups (sum of the MNI of cereals, pulses, fruits) was tested with Fisher's exact test of independence, which is the most suitable statistical test for non-parametrical small samples. The tests were computed with the software R (R Core Team 2015).

The charcoal analysis is based on the number of remains, which corresponds to the number of identified fragments of each taxon. It appears from the number of samples and remains that the different phases and terraces are not comparable across time (see below, Table 1). In order to reduce the effect of methodological bias, only the largest assemblage, from the late Roman period, is quantitatively described with relative proportion and frequency computations, whereas the smallest ones are only discussed qualitatively.

\section{Results}

\section{The carpological remains}

The carpological assemblage consists of 7,640 items, including a mix of fragmented and whole remains. All of them are charred, except the mineralized nutlets of the Boraginaceae. 141 items $(1.8 \%)$ were not identifiable. The discrepancies in the numbers of plant macro-remains between periods and terraces are mainly explained by the differences in preservation of organic material according to excavation area and archaeological context, as well as the representativeness of the different cultural layers at ez-Zantur (Table 1). As a result, the Nabataean (number of samples, $n=19$; number of remains, $N R=3,121$ ) 
and late Roman $(n=23 ; N R=3,405)$ periods are better represented than the Early Nabataean $(n=11 ; N R=496)$, Roman $(n=5 ; N R=345)$ and Byzantine $(n=4$; $\mathrm{NR}=273$ ) periods.

The carpological remains are represented by a minimum of 62 taxa, which have been separated into groups according to economic and/or ecological criteria. The cultivated plants group includes cereals, pulses and fruits; the wild plants group consists of weeds associated with fields and gardens, ruderals, plants from steppe, desert or woodland plant communities and other unspecific wild plants (Table 2). In order to highlight change with time, cultivated and wild plants are presented separately in the results.

\section{Cereals}

The cereals group consists of at least three different species preserved in the form of grains or by-products, Hordeum vulgare (hulled barley), Triticum aestivum/durum (bread/hard wheat) and T. turgidum ssp. dicoccon (emmer wheat). Around $65 \%$ of the total number of remains of the grains and by-products could not be identified to species level because of poor preservation or the absence of diagnostic elements (Table 2). Cereal by-products such as rachis fragments, bracts, culm nodes and root fragments are present in small quantities through time and do not exceed $8 \%$ of the total number of cereal remains (Ez II, Nabataean period, Table 2). They are absent from the Roman and Byzantine layers. The few badly preserved barley rachis fragments do not allow identification of Hordeum vulgare ssp. distichon/vulgare (2 row or 6 row barley). Similarly, rachis fragments of free-threshing wheat cannot be clearly attributed to T. turgidum ssp. durum or T. aestivum ssp. aestivum.

Barley and free-threshing wheat are present in each terrace and period, except in Ez I during the Roman period. The relative abundance (MNI) and ubiquity proportion of barley are more important than those of free-threshing wheat from the Early Nabataean to the late Roman period (Fig. 3). All wheat caryopses seem to belong to free-threshing wheat, but some emmer rachis nodes were recognized among the samples of the Early Nabataean and Late Roman periods. 


\section{Pulses}

The pulses were quite damaged and many are identified as indeterminate Fabaceae, around $50 \%$ of the total number of pulses remains per terrace (Table 2). Nevertheless, six species are recognized, all belonging to well-known pulses domesticated in the Near East during the Neolithic period (Zohary et al. 2012, pp 77-95). Lens culinaris ssp. culinaris (lentil) is present in all terraces and periods, except in Ez II during the Early Nabataean period and Ez I during the late Roman period. Vicia ervilia (bitter vetch), Cicer arietinum ssp. arietinum (chickpea), Pisum sativum (pea), Vicia cf. faba (fava bean) and Vicia sativa (common vetch) are sporadically present in smaller quantity $(<2 \%)$. All the pulses are present in Ez IV during the late Roman period.

\section{Fruit and nuts}

Potentially domesticated fruit and nuts are Ficus cf. carica (fig), Juglans regia, Olea europaea, Phoenix dactylifera, Prunus armeniaca (apricot), P. persica (peach) and Vitis vinifera. Ficus, Olea and Vitis, the three kinds of fruit that were the most cultivated throughout the Mediterranean basin since the Chalcolithic/Bronze Age (Tengberg 2012), are continuously present in all areas and periods at ez-Zantur (Table 2). Each of them reaches different high records of relative abundance and ubiquity proportion in the various terraces and periods. For instance, fig achenes are present in $40 \%$ of the samples during the Early Nabataean period in Ez II and reach $35 \%$ of the MNI of cultivated plants in Ez IV during the Late Roman period (Fig. 3). Olive, which is mainly found in the form of broken stones ( $98 \%$ of the total number of olive stones, Table 2), is present in more than $60 \%$ of the samples from the Nabataean to the Byzantine period and reaches $77 \%$ of the MNI of cultivated plants in Ez III during Roman period (Fig. 3). Grape pips are well represented during the Nabataean period in Ez III, in which they are present in $73 \%$ of the samples and constitute $58 \%$ of the MNI of cultivated plants (Fig. 3). Beside these three important Mediterranean fruits, one characteristic Middle Eastern species, Phoenix dactylifera (date palm), is less abundant, but it is regularly found in the form of fruit stones from the Early Nabataean period. Its ubiquity proportion fluctuates from 25 to $36 \%$ until the Byzantine period (Fig. 3). Finally, two fruit stones of Prunus persica and one of $P$. armeniaca as well as three Juglans regia (walnut) fragments were found in 
domestic sediment layers associated with the Late Roman mansion in the Ez IV terrace.

\section{The wild taxa}

At least 46 taxa are potentially wild plants that are likely to have grown naturally in Petra. The majority of the plant list cannot be safely attributed to a specific ecological group because of the low identification level of most of the taxa. Indeed, only four species are identified, whereas 32 taxa are identified to genus level, with five doubtful identifications (cf.), and ten taxa are identified to family level (Table 2). Nevertheless, some of the taxa are clearly wild plants from natural habitats and others are plants that are potential indicators of areas of human activity. Moreover, we cannot exclude that some of these wild plants might have been processed and maybe cultivated for specific purposes, such as for medicinal uses.

Two Mediterranean woody taxa (Crataegus sp., Pistacia sp.) are recognized from the Early Nabataean and Nabataean periods. Shrubby plants characteristic of desert or steppe habitats, such as Capparis sp. (caper) and Amaranthaceae only appear during the Nabataean and Late Roman period. Amaranthaceae seed accumulations $(\mathrm{NR}=639)$ are observed in four samples from the household area of Ez IV (Table 2).

Other wild plants are irregularly distributed though time and between terraces and these are only quite well represented in Ez III during the Nabataean period and in Ez IV during the Late Roman period (Table 4). The comparison of these two assemblages shows that the most frequent seeds, present in both terraces, are Silene sp., Asperula/Galium, Melilotus/Trifolium, Fumaria sp. and Medicago sp. These genera include common Near Eastern weeds which grow in non-irrigated winter crop fields and belong to the Secalinetea class (Zohary 1973, pp 636-643). Other less frequent taxa probably correspond to weeds, although most could also have been ruderals, growing on disturbed ground such as abandoned fields and roadsides or even coming from other habitats, as it is known that the segetal flora becomes less specific and different from the surrounding non-segetal flora as it gets closer to desert conditions (Zohary 1973). Several strictly annual or perennial ruderals are recognized (Erodium sp, Malva cf. parviflora, Plantago sp.). No specific weeds of irrigation crops were identified, apart from three genera, 
Amaranthus sp., Setaria (verticillata) and Heliotropium sp., that contain species which correspond to the Panicetea hydro-segetalis class of plant communities of irrigated summer crops (Zohary 1973). The attempt to classify taxa according to phytosociological criteria (Zohary 1973, pp 636-643) appears unconvincing, mainly because of the low resolution of the dataset. After all, the most conclusive result is the change of the taxonomic spectra between the Nabataean and the Late Roman period. Indeed, 11 taxa are only represented in Nabataean layers whereas six taxa and two doubtful identifications are present only in Late Roman contexts (Table 4).

\section{Wood charcoal analysis}

The total number of wood charcoal fragments in the archaeological samples is very small, probably because of the selection process of the archaeological samples that was initially planned for seeds and fruit studies only. All the wood charcoal elements that could be collected (Number of remains, $N R=624$ ) were examined and 617 of them identified (98.9\%). Most of the fragments correspond to Late Roman layers ( $\mathrm{n}=15$ samples, $\mathrm{NR}=439)$ in Ez IV. Early Nabataean $(\mathrm{n}=10$, $\mathrm{NR}=43)$ and Nabataean $(\mathrm{n}=9, \mathrm{NR}=142)$ layers are very poorly represented and no charcoal was found in the samples from the Roman and Byzantine periods (Table 1). As wood charcoal fragments were found in the various household areas of ezZantur (Table 5) where no traces of fires were observed, they must be considered as fuel residues (Théry-Parisot et al. 2010). They are composed of 19 taxa classified into four large ecological communities: cultivated fruits, desert plants, open woodland and riverside woodland. The small number of charcoals analysed from the Early Nabataean and the Nabataean periods does not constitute a representative dataset for examining fuel use, and so a mainly qualitative description is given. On the other hand, the data for the Late Roman period with 15 samples and 439 fragments are described quantitatively.

\section{Cultivated fruits}

Fruit growing is represented by olive, grapevine and fig. Olive is the only one found from the Early Nabataean to the Late Roman period. It constitutes $41 \%$ of the total number of charcoal fragments during this last period. Although no precise measurement of the wood diameters was made, it was noted that very 
small pieces, less than $5 \mathrm{~mm}$, were common in the assemblages. Fig wood only appears in the Nabataean period in Ez I and grapevine in the Late Roman period in $\mathrm{Ez}$ IV (3\% of the total number of remains).

\section{Desert plants}

Amaranthaceae shrubs and Acacia are two typical desert woody plants growing in sandy plains in the Near East. Charcoal fragments of these two taxa are present in all periods. Acacia charcoal constitutes the second dominant taxon of the Late Roman assemblage with $17 \%$ of the total number of remains. It is also particularly present in Ez I during the Nabataean period, where it constitutes half of the total charcoal.

\section{Open woodlands}

Eleven taxa are shrubs or trees characteristic of the Mediterranean open woodland vegetation formations commonly found on Jordanian mountain slopes (Zohary 1973). Among them, four taxa are ubiquitous, Pistacia sp. (pistachio), Quercus calliprinos-type (an evergreen oak), Juniperus sp. (juniper) and Fabaceae (legumes). All the Fabaceae fragments have a similar anatomy characterised by the presence of vessels in an oblique to dentritic pattern together with the paratracheal parenchyma in transversal section. Furthermore, in longitudinal tangential section, vessels are weakly storied with axial parenchyma. These criteria fit well with some of the species of the subfamily of shrubby brooms (Faboideae) (Fahn et al. 1986, pp 119-125), like Retama raetam (white broom), which grows both in the desert areas and on rocky slopes at Petra today (Ruben 2006). Although Fabaceae fragments are ubiquitous, they constitute a small fraction ( $7 \%$ of the total number of remains) during the Late Roman period, similar to juniper (2\%) and evergreen oak (0.5\%). Only Pistacia reaches $11 \%$ of the total number of remains. Charcoal fragments of Cistus sp. (cistus), Cupressus sempervirens (cypress), Pinus sp. (pine.), cf. Prunus sp. and Quercus ithaburensis-type (a deciduous oak) are only noted during the Late Roman period and in small percentages $(<3 \%)$. 


\section{Riverside woodland}

Platanus orientalis (oriental plane), Salix sp. (willow) and Tamarix sp. (tamarisk) are typical trees of riverside woods which grow beside the seasonal rivers in the southern Near East. They can also be planted in irrigated gardens. Tamarisk charcoal fragments are continuously present, whereas plane and willow only reach small percentages during the Late Roman period $(<2 \%)$.

\section{Comparison of carpological and charcoal remains}

Several taxa are found both in carpological and wood charcoal assemblages (Table 6). They mainly correspond to potentially cultivated fruit, Olea, Ficus and Vitis and, to a lesser extent, trees and shrubs growing in their natural habitats, such as Acacia, Pistacia and Amaranthaceae. No other fruits of the wild trees recognized through the wood charcoal analyses have been identified in the carpological study, such as conifer cones or acorns. The woody taxa identified in the carpological study but absent from the charcoal results are Crataegus, Capparis, Phoenix dactylifera, Prunus persica and P. armeniaca, although the doubtful identification of ring-porous cf. Prunus sp. charcoal might correspond to one of the latter two fruit trees.

\section{Discussion}

\section{Limits and meaning of the archaeobotanical assemblage from ez-Zantur}

The rich and diverse plant remain assemblage from ez-Zantur gives us a unique opportunity to understand the farming and environment at Petra. However, the dataset presents several methodological biases that should be addressed in order to rule them out of the discussion.

First, a Fisher's exact test was done on the carpological results to analyse the significance of the association of the contemporary terraces according to the three groups of cultivated plants, cereals, pulses and fruit. The results show that there is no significant difference between Ez I and Ez II during the Early Nabataean period ( $\mathrm{p}=0.163$ ), little significant difference between Ez I and Ez III during the Nabataean period $(\mathrm{p}=0.002)$ and strong significant difference between $\mathrm{Ez}$ I and $\mathrm{Ez}$ 
IV $(p<0.05)$ during the Late Roman period. However, the irregular distributions of the number of samples and remains obviously affect these results. Moreover, we assume that the stochastic effect (random process) is very high, resulting from the plant accumulation rates, sampling strategies and use practices. The same Fisher's exact test was done by adding the MNI of each category (cereals, pulses, fruits) for contemporary terraces in order to evaluate the significance of the association between the different periods. This showed that the Early Nabataean period is significantly different from the Nabataean period $(\mathrm{p}<0.05)$ and from the Late Roman period $(\mathrm{p}<0.05)$. Similar results were obtained by taking into account the MNI weight according to the sampled volume. These results allow us to assume that the distribution of the relative abundance and ubiquity proportion of the cultivated plants between the Early Nabataean period, on the one hand, and Classical Nabataean and Late Roman periods on the other, show two main tendencies (Fig. 6) characterized by differences in records of cereals and fruit. Cereal percentages decrease from the Early Nabataean period (64-80\% of the cumulative MNI, $80 \%$ of ubiquity) to the Late Roman period ( $4-23 \%$ of the cumulative MNI, 50-90\% of ubiquity). The fruit, especially olive, fig and grape, generally increases from the Early Nabataean period (9-16 \% of the cumulative MNI, 20-40 \% of ubiquity according to the species) to the Late Roman period (53-96 \% of the cumulative MNI, 50-100 \% of ubiquity according to the species). In parallel, detailed examination of changes in fruit values shows important species differences between terraces, independent of the chronology (Fig. 5). For instance, during the Nabataean period, olive is dominant in Ez I (36 \% of MNI, $100 \%$ of ubiquity), whereas grape dominates in Ez III (58 \% of MNI, $73 \%$ of ubiquity. We assume that this reflects differences of fruit plant use and diversity of practices, as discussed below.

Secondly, several taxa commonly found in the carpological assemblage are absent from one period or one terrace, for example free-threshing wheat and lentil are absent from Ez II during the Nabataean period and Ez I during the Late Roman period, or free-threshing wheat and barley during the Roman period. It is certain that these absences are the result of preservation and sampling effects rather than actual spatial or chronological differences. Likewise, the weak representativeness of the wild taxa during the Early Nabataean and Roman periods should probably be considered to be due to these methodological factors, even other explanations, 
such as the rarity of dung use as fuel in these specific contexts, might also be involved; see below, on fuel management).

Finally, as already noted, the wood charcoal spectra are very poor, especially for the Early Nabataean and Classical Nabataean periods, and the quantitative results cannot be compared for the discussion of change over time. Only the results from the Late Roman period are discussed quantitatively to provide some insights into the sources of fuel.

\section{The presence of a Mediterranean farming system in the Early Nabataean period}

\section{Regional inheritance and continuity}

The most frequent species present at ez-Zantur are cultivated plants that are continuously present through the various occupation periods. Cereals (hulled barley and naked wheat), pulses (lentil, pea, bitter vetch) and fruit trees (olive, grape, fig, date palm) are found from the early Nabataean period and the qualitative spectra remain nearly the same during the following periods. These plants represented a common food supply for both humans and animals in the ancient Near East. The slight presence of emmer rachis could show that it was sometimes grown or it could be considered as a contaminant in the fields of freethreshing wheat (Cappers 2006, p 131). The other archaeobotanical studies conducted in ancient Petra and its hinterland show very similar plant spectra, despite the specific nature of the contexts, whether religious (Tholbecq et al. 2008), funerary (Sachet et al. 2013) or garden spaces (Ramsay and Bedal 2015), and the small number of samples in some cases (Table 7; Neef 1987, 1990). The results are very similar to those from other archaeobotanical analyses conducted in the southern Near East (Gilliland 1986; Crawford 1987, 2006; Willcox 1992, 2003; Hoppé 2012; Ramsay 2013). All of these help us to understand which crop plants were grown in this semi-arid region characterised by the growing of freethreshing wheats, hulled barley and Mediterranean fruit (Bouchaud 2015), a triad inherited from at least the Bronze Age (Tengberg 2012). It is however difficult to know whether the inhabitants of ez-Zantur cultivated the various crops themselves, and if they did, the location of the irrigated or rain-fed fields. Otherwise they might have obtained their food from another farming community. 


\section{Local farming within and outside the city centre}

Several results support the idea that farming was well developed in the centre of Petra from the early beginning of the Nabataean occupation. The strong presence of fruit by-products in the form of seeds, stones and wood charcoal reveals the regular use of edible products as food and inedible by-products as fuel (see below), probably coming from neighbouring plots. This is particularly well demonstrated for the olive, from which all the different plant elements were found from each period of occupation. With the discovery of a round rotary olive crusher in the substructure of the Nabataean house of Ez IV dated to the late 2nd or early 1st century BC (Kolb and Keller 2001), these archaeobotanical data give direct evidence of farming under Nabataean and then Roman rule, contrary to Strabo's claim that no olive trees grew in the Nabataean territory (Geography, XVI.4.26, Jones 1961). The presence of vineyards and fig groves is also clearly shown by the regular presence of pips and wood. The rarity of the date palm fruit stones and the complete absence of trunk or leaf remains in the charcoal assemblage probably together demonstrate that dates were rarely cultivated and consumed in Petra. Perhaps date palm only grew in some specific gardens, as in the Petra garden and pool complex, where phytolith analyses have revealed its presence (Ramsay and Bedal 2015).

Secondly, the small but consistent amounts of cereal chaff, straw remains and weeds resulting from post-harvesting processing probably indicate local farming, as is the case for the regional ancient farming sites in the southern Near East, for instance at Bir Madhkur (Ramsay and Smith II 2013), or other more distant contemporary archaeological sites (Gilliland 1986; Crawford 1987, 2006; Willcox 1992, 2003; Hoppé 2012; Ramsay 2013). Nevertheless, the proportions of cereal by-products at ez-Zantur are much lower than at other farming sites, like Dharih in the north (Bouchaud 2015) or Humayma in the south (Ramsay 2013), where charred chaff and straw constitute more than $50 \%$ of the cereal remains. As it is highly unlikely that these by-products were not used as fuel, fodder or temper in such a semi-arid environment (van der Veen 1999), one can assume that the cereal spikes were processed elsewhere, whereas only the grains, or florets together with accidental by-products and weeds, reached ez-Zantur. One of the last stages of cereal processing, grinding, is directly demonstrated at ez-Zantur by the presence 
of milling installations dated from the last few centuries BC (Grawehr 2010, pp 209-211).

Although the interpretation of the cereal assemblage is not completely conclusive, the presence of charred fruit tree and vine remains, indicates without doubt that the cultivation plots were located not far from ez-Zantur. It is highly probable that some of the inhabitants were involved in the cultivation of small fields in the neighbouring area, for instance along the various seasonal watercourses, or on the terraces in the direction of jabal Harun (Fig. 1), as is the case today, from the Early Nabataean period and during all periods of occupation. In parallel, archaeological surveys show the increasing presence of farming structures in the area around Petra during the Nabataean period that suggest that some of the foodstuffs for the inhabitants of the city centre would have been provided from there (Kouki 2012; Tholbecq 2013). It is worth considering that this was partially the case for the inhabitants of ez-Zantur, notably for the cereals, which could explain why the proportions of by-products are so low. Nevertheless, it is likely that small-scale growing of cereals and/or pulses was done under the fruit trees and vines inside the city, following the traditional examples of a Mediterranean farming system where annual and perennial plants are mixed in order to benefit each other (Eichhorn et al. 2006).

The apparent uniformity of farming, mainly based on Mediterranean fruit, freethreshing wheat and hulled barley, should be qualified by a more realistic view of its adaptation to ecological and cultural aspects that probably led to the existence of many varieties of each crop, as was always observed in the 20th century (Russell 1995, p 696). A good illustration of this view concerns the results of the morphometric study previously conducted on some of the grape pips found in the Nabataean levels of Ez III, which showed the presence of various morphotypes, some of which are wild (Jacquat and Martinoli 1999). As demonstrated in the western Mediterranean, this probably indicates the cultivation of a mixture of grape vine types, ranging from morphologically wild to domesticated, rather than harvesting practices (Bouby et al. 2013). Indeed, harvesting methods for food are almost invisible in the results from ez-Zantur, as in the other regional archaeobotanical results. For instance, pistachio fruit remains are only represented by some endocarp fragments, whereas pistachio wood seems to have been largely 
used for fuel, as shown by the continuous presence of charcoal fragments (Table $5)$.

\section{Fuel management: wood gathering and use of the by- products from farming and herding}

The use of wild trees and shrubs was mainly for firewood rather than for food. The analysis of the wood charcoal assemblages shows the use of various vegetation types (Table 5). Woods possibly growing on rocky slopes, with pistachio, juniper and evergreen oak above 1,200 $\mathrm{m}$ and Fabaceae and pistachio between 800 and 1,200 m, sandy plains with acacia and Amaranthaceae and tamarisk probably growing on the banks of wadis are represented during the Early Nabataean, Nabataean and Late Roman periods, demonstrating use of various types of woody vegetation around Petra. The quantitative data from the Late Roman period show that pistachio and acacia were the main trees used and each was likely to have grown in the vicinity, the first just above the ez-Zantur terraces, such as around jabal Umm al-Biyarah, and the second on the sandy plains, such as along the wadis al-Farasah and al-Matahah (Fig. 1). The many other taxa found from the Late Roman period provide new indices of the richness of the local biodiversity of the open woodland and riverside woods, and highlight the ability of the inhabitants to manage a large variety of fuel resources. This practice is also particularly expressed through the dominant presence of agricultural waste resulting from fruit tree cultivation. The systematic discoveries of olive stone fragments and wood charcoal, among which small diameter pieces were present, result from the common practice in the Near East of the use of prunings and pressed fruitstones as fuel (Neef 1990; Warnock 2007; Marinova et al. 2011).

Olive residues are still considered a high quality fuel in most of the Mediterranean countries (Nefzaoui 1988; Zabaniotou et al. 2000, Braadbaart et al. 2016) and their ubiquity at ez-Zantur perhaps suggests that they were stored to provide a permanent fuel supply. The use of grapevine remains is shown by the presence of abundant charred seed and pedicel remains in the Nabataean layers of Ez III, probably corresponding to the direct use of grapevine waste after pressing (Jacquat and Martinoli 1999; Margaritis and Jones 2006), as well as wood charcoal during the Late Roman period resulting from prunings. During the Nabataean period, the strong presence of grapevine residues in Ez III, while olive 
residues dominate in Ez I, shows that there were probably various supply networks from the places of cultivation and processing according to the availability of resources. In addition to wild woody plants and by-products from cultivated plants, the presence of charred sheep of goat droppings (Table 2) would show their use as fuel. Livestock were probably kept in Petra centre since the Nabataean population began living inside the city, and so sheep and goat dung would have been continuously available (Studer 2002). Although no strict correlation is observed between the distribution of wild plants and weeds and sheep/goat dung remains, it is likely that some of the wild plants, especially the ruderal ones, reveal the original presence of dung in the samples that disappeared with carbonization (Miller and Smart 1984; Charles 1998).

The archaeobotanical results from ez-Zantur cannot be used for palaeoenvironmental reconstruction due to methodological bias. However, such studies have been conducted in wadi Faynan south of Petra and they indicate loss of woodland due to increased human activities related to copper extraction, between the Bronze Age and the Byzantine period (Barker et al. 1998; Hunt et al. 2007). In Petra, the single pollen study, made on fossil Procavia capensis (hyrax) middens, leads to a similar conclusion, although the small assemblage prevents generalization of the conclusion and the chronology should be revised in the light of recent research (Fall 1990). Considering the intense urbanisation process in Petra from the Early Nabataean period, and the development after the 1st century BC of specialised craft activities, like making pottery (Schmid 2000) or metalworking (Ryzewski et al. 2011), the collection of firewood would have been important. On the one hand, our results show a great diversity of plants during the Late Roman period, perhaps underlying a modest human impact on biodiversity. On the other hand, the multiplicity of the fuel resources for household consumption, notably the presence of crop by-products and dung, probably shows a certain shortage of natural woody vegetation, while demonstrating a great ability to manage collection and redistribution of fuel. 


\section{Chronology of Ez-Zantur as a reflection of the farming and economy of Petra}

\section{Toward specialization in fruit growing}

The quantitative data of the plant macro-remains (Fig. 4) suggest an increase in fruit growing, especially olives and grapes, between the Early Nabataean period later in the Nabataean, Roman and Late Roman periods. The decrease in fruit remains during the Byzantine period is difficult to consider since the sampling effect is probably important; results for this period are therefore excluded from the discussion. The hypothesis of specialization in fruit growing in Petra from the Nabataean period, after the middle of the 1st century BC, must be considered, especially as other lines of evidence show the same tendencies. First, the pollen record from Petra contains its highest value of Olea pollen between the 2nd and 4th century AD (Fall 1990). Secondly, archaeological structures linked with oil or wine production in and around Petra developed from the 1st century AD (AlMuheisen 1990; Zeitler 1990, 1991, 1993; 'Amr et al. 2000; 'Amr and al-Momani 2001; Al-Salameen 2005). Third, the development of complex water management systems at the end of the 1st century BC throughout the entire city (Ortloff 2005; Al-Muheisen 2009; Beckers et al. 2013) may be partly linked with the needs of farming, as this would make the cultivation of some plants easier. None of the weeds directly confirms the presence of irrigation practices, except three potential taxa (see results) that cannot be linked with precise crops, but the presence of grape remains, from a plant which needs enough water, should indicate that these crops were irrigated. Similarly, willow and poplar during the Late Roman period could represent trees that were planted in irrigated gardens rather than those growing in natural riverside woods. Specific references to Nabataean irrigated gardens are found in the description by Strabo (Geographia XVI.4.21, Jones 1961), in the excavation of the Petra garden and pool complex (Bedal 2013; Ramsay and Bedal 2015) and the possible gardens of the Nabataean royal residence at the foot of al-Khubthah (Schmid et al. 2012, Fiema and Schmid 2016). However, these references more probably refer to pleasure gardens (paradeisos in Greek) rather than ones for growing crops for food. In the area around Petra, the archaeological surveys point to well-developed run-off systems as well as cisterns and water pipes (Kouki 2012; Tholbecq 2013). The Petra 
papyri found in a storage room in a Byzantine church and dated to the 6th century $\mathrm{AD}$, after the chronological interval represented by the archaeobotanical remains of ez-Zantur, provide useful data on land settlement in Petra and its surroundings which have many similarities to what is proposed for the preceding periods. They show the presence of irrigated orchards and xerokeppia (literally dry gardens) near the houses in and around the city, vineyards on the rocky soils and sown terraced fields near the slopes to take advantage of run-off (Frösen et al. 2002; Arjava et al. 2007; 2011; Nasarat et al. 2012; Koenen et al. 2013). The scroll contents do not provide detailed information on the cultivated crops, crop rotation or potential associations of annual and perennial plants, nor any mention of olives. As it is unlikely that olives disappeared from the Petra city centre between the 5th century, when they were recorded for the last time in the ez-Zantur area, and the 6th century, it should be considered that the so-called xerokeppia included these trees, as well as other drought-tolerant plants, such as barley and hard wheat, possibly in rotation with lentils, as is seen in the modern traditional methods of farming (Palmer 2001). As a result, the Petra papyri, like the archaeological and archaeobotanical studies, show the permanence of complex farming systems in Petra which took advantage of the contrasting topography by choosing adapted plants and improving both water management systems and run-off farming. In parallel to the continuity of the crop selection, several archaeological elements suggest some changes to the land plots used over time. For instance, the western and eastern hinterlands of Petra show intense agricultural activities during the Nabataean period (Kouki 2012; Tholbecq 2013), but the eastern part was apparently less used during the Late Roman period, probably because of soil erosion due to human impact (Tholbecq 2013). This would probably be true as well in other parts of Petra, although the current state of knowledge makes it difficult to detect such spatial and chronological changes (Besançon 2010). If we assume that most of the wild seeds and fruits found correspond to post-harvest processing and the burning of dung, their presence in relation to their ecological qualities may indicate from where they came and the different eco-systems exploited. Sadly, the low resolution of a large part of the identified material and the non-specific ecological requirements of various taxa prevent any spatial reconstruction of the different areas used and their changes through time. Only the 
radical differences in weed composition between the Nabataean and Late Roman periods (Table 4) perhaps indicate the moving of the land plots.

It is thus worth considering that urban development in Petra during the second half of the 1 st century $\mathrm{BC}$ goes along with pronounced changes in farming which are characterised, not on the selection of new crops, but on the development of farming structures and the growing of well-known perennial fruit. None of the written data provide any indication on potential cash crops from Petra. Even if the local use of the produce was clearly the priority, we should consider that some of it, especially that from grape and olive, may have been involved in a small regional trade, invisible in the literature (Bouchaud 2015).

\section{Prosperity of the city during the Late Roman period: the evidence from Ez IV}

From the archaeological studies, it is now clearly established that there were high quality residential complexes from the Nabataean to Late Roman periods on the Ez IV terrace, and that the inhabitants were wealthier than those on the Ez I and Ez III terraces. Indeed, numerous fine rooms have been found together with a residential part, a heating system, thin pottery and glass, and sophisticated wall paintings (Kolb and Keller 2000, 2001). Furthermore, the faunal spectra from Ez IV are characterized by greater wild and domestic bird consumption than in Ez I, pointing to particular food practices (Studer 2002, 2007). The archaeobotany results show that beside the common cultivated plants found in the various terraces, three new foodstuff remains were found only in Ez IV, apricot, peach and walnut. They represent regular but very rare discoveries in the semi-arid regions of the Near East during antiquity.

Apricot and peach were probably introduced during the second half of the 1st millennium BC to the Near East from Eastern or Central Asia (Zohary et al. 2012, $\mathrm{p}$ 144). To date, apricot and peach records in southwest Asia have been mostly reported from Egypt in Ptolemaic and Roman sites (Germer 1985, p 61; Thanheiser 2002; Cappers 2006, p 122; van der Veen 2011, p 155). In the southern Near East, peach and a few apricot stones were found in funeral, religious, military or harbour contexts dating to Roman and Byzantine times (Mayerson 1986; Crawford 1987; Ramsay 2010; Bouchaud et al. 2011; Hoppé 2012). For walnut, pollen records (Leroy 2010; Neumann et al. 2010) and macro- 
remains analyses (Zaitschek 1962; Kislev 1992; Simchoni and Kislev 2009) around the Dead Sea show the increase of its cultivation from the 4th-3rd century BC. However, walnut evidence in other areas of the southern Near East are scarce and limited (Mayerson 1986; Ramsay 2010; Bouchaud et al. 2011). The rarity of these discoveries shows that apricot, peach and walnut were uncommon foodstuffs in the Petra region, as has been suggested for Egypt (Cappers 2006, p 122; van der Veen 2011, p 155). While these fruits were possibly sporadically cultivated in Petra, for instance in irrigated pleasure gardens, they may also have been brought to the city by merchant caravans, fresh or dried with the fruit stones still enclosed for apricot and peach (van der Veen 2011, p 155). Whether they were traded or locally cultivated, these fruits are likely to represent delicacies intended for a small part of society.

\section{Conclusions}

This integrative study of carpological and wood charcoal remains from the ezZantur terraces in Petra offers new insights on past agricultural systems and economies through time, from the Early Nabataean period to the Byzantine period. Staple food was largely, if not only, directly obtained from local fields both near the city centre and in the surroundings, and we assume that some of the inhabitants of ez-Zantur were involved in the production and processing of crops plants during all of the occupation phases. The results show that the inhabitants of Petra, characterised by their Nabataean culture as identified from archaeological and historical evidence, followed farming methods directly inherited from the preceding periods and based on irrigated and rain-fed cultivation of hulled barley, free-threshing wheats and Mediterranean fruit, offering an adapted and durable response to environmental constraints while ensuring economic autonomy. Fuel supplies were integrated with farming, allowing complete use of pruning and crop processing waste in addition to wood gathered from plant communities on the rocky slopes and sandy plains. In parallel, the archaeobotanical results reflect the economic dynamics of the city, showing the presence of specialised fruit growing from the Nabataean period, perhaps partly intended for trade. The rare food items in the richest houses of the ez-Zantur terraces may have been obtained from orchards or by trade, and these items can be interpreted as social indicators of prosperity. 
Acknowledgments Funding for this work was provided by the Swiss-Liechtenstein Foundation for Archaeological Research Abroad (SLSA) and the Institute of Plant Biology of Zürich University. Our thanks go particularly to the project directors R.A. Stucky and B. Kolb (University of Basel, Switzerland), to Matthias Grawehr (Unibas, Basel), Nicolas Giret (CNRS, Orsay) and the two anonymous reviewers for their remarks and re-readings, and to Rebecca Miller for the English editing.

\section{References}

Al-Muheisen Z (1990) Exemples d'installations hydrauliques et des techniques d'irrigation dans le domaine nabatéen (Pétra, Jordanie méridionale). In: Geyer B (ed) Techniques et pratiques hydro-agricoles traditionnelles en domaine irrigué. Geuthner, Paris, pp 507-511

Al-Muheisen Z (2009) The water engineering and irrigation system of the Nabataeans. Yarmouk University, Irbid

Al-Salameen Z (2005) Nabataean wine-presses from Bayda, southern Jordan. Aram 17:115-127. doi: 10.2143/ARAM.17.0.583324

'Amr K, al-Momani A (2001) Preliminary report on the archaeological component of the Wadi Musa water supply and wastewater project (1998-2000). Adaj 45:253-285

'Amr K, al-Momani A, al-Nawafleh N, al-Nawafleh S (2000) Summary results of the archaeological project at Khirbat an-Nawafla/Wadi Musa. Adaj 44:231-255

Anderberg A-L (1994) Atlas of seeds and small fruits of Northwest-European plant species with morphological descriptions. Part 4: Resedaceae-Umbelliferae. Swedish Museum of Natural History, Stockholm

Arjava A, Buchholz M, Gogos T (2007) The Petra papyri III. American Center of Oriental Research, Amman Arjava A, Buchholz M, Gagos T (2011) The Petra papyri IV. American Center of Oriental Research, Amman Barker GW, Adams R, Creighton OH et al. (1998) Environment and land use in the Wadi Faynan, southern Jordan: the second season of geoarchaeology and landscape archaeology (1997). Levant 30:5-25

Beckers B, Schütt B, Tsukamoto S, Frechen M (2013) Age determination of Petra's engineered landscape optically stimulated luminescence (OSL) and radiocarbon ages of runoff terrace systems in the Eastern Highlands of Jordan. J Archaeol Sci 40:333-348. doi: 10.1016/j.jas.2012.06.041

Bedal L-A (2013) The Petra pool-complex. A Hellenistic paradeisos in the Nabataean capital. Results from the Petra "Lower Market" survey and excavation, 1998. Gorgias Press, Piscataway

Bellwald U (2006) The hydraulic infrastructure of Petra. A model for water strategies in arid land. In: Wiplinger G (ed) Cura aquarum in Ephesus: Proceedings of the 12th International Congress on the history of water management and hydraulic engineering in the Mediterranean region. Peeters, Louvain, pp 225-235

Berggren G (1969) Atlas of seeds and small fruits of Northwest-European plant species with morphological descriptions. Part 2: Cyperaceae. Swedish Natural Science Research Council, Stockholm Berggren G (1981) Atlas of seeds and small fruits of Northwest-European plant species with morphological descriptions. Part 3: Salicaceae-Cruciferae. Swedish Natural Science Research Council, Stockholm 
Besançon J (2010) Géographie, environnements et potentiels productifs de la région de Pétra (Jordanie). In: Gatier P-L, Geyer B, Rousset M-O (eds) Entre nomades et sédentaires. Prospections en Syrie du Nord et en Jordanie du Sud. De Boccard, Paris, pp 19-71

Bienkowski P (1990) Umm el-Biyara, Tawilan and Buseirah in retrospect. Levant 22:91-109

Bienkowski P (2013) The Iron Age in Petra and the issue of continuity with Nabataean occupation. In:

Mouton M, Schmid SSG (eds) Men on the rocks. The formation of Nabataean Petra. Logos, Berlin, pp 23-34

Bignasca A, Desse-Berset M, Fellmann Brogli R et al. (1996) Petra Ez-Zantur I: Ergebnisse der schweizerisch-liechtensteinischen Ausgrabungen 1988-1992. Von Zabern, Mainz

Bouby L, Figueiral I, Bouchette A et al. (2013) Bioarchaeological insights into the process of domestication of grapevine (Vitis vinifera L.) during Roman Times in southern France. PloS one 8:e63195

Bouchaud C (2011) Paysages et pratiques d'exploitation des ressources végétales en milieux semi-aride et aride dans le sud du Proche-Orient: Approche archéobotanique des périodes antique et islamique (IVe siècle av. J.-C.-XVIe siècle ap. J.-C.). Dissertation, University of Paris 1 Panthéon-Sorbonne

Bouchaud C (2015) Agrarian legacies and innovations in the Nabataean territory. ArcheoSciences 39:103-124

Bouchaud C, Sachet I, Delhopital N (2011) Les bois et les fruits des tombeaux nabatéens de Madâ'in

Sâlih/Hégra (Arabie Saoudite): les provenances des végétaux et leur utilisation en contexte funéraire. In:

Delhon C, Théry-Parisot I, Thiébault S (eds) Des hommes et des plantes. Exploitation et gestion des ressources végétales de la Préhistoire à nos jours. Anthropobotanica 1. APDCA, Antibes, pp 3-21

Braadbaart F, Marinova E, Sarpaki A (2016) Charred olive stones: experimental and archaeological evidence for recognizing olive processing residues used as fuel. Veget Hist Archaeobot 25:415-430

Byrd BF (2005) Early village life at Beidha, Jordan: Neolithic spatial organization and vernacular architecture. Oxford University Press, Oxford

Cappers RTJ (2006) Roman foodprints at Berenike: archaeobotanical evidence of subsistence and trade in the Eastern Desert of Egypt. Cotsen Institute of Archaeology, University of California Press, Los Angeles

Cappers RTJ, Neef R (2012) Handbook of plant palaeoecology. Barkhuis, Groningen

Cappers RTJ, Neef R, Bekker RM (2012) Digital atlas of economic plants in archaeology. Barkhuis, Groningen

Charles M (1998) Fodder from dung: the recognition and interpretation of dung-derived plant material from archaeological sites. Environ Archaeol 1:111-122

Crawford P (1987) Food for a Roman Legion: the plant remains from el-Lejjun. In: Parker ST (ed) The Roman frontier in central Jordan. Interim report on the Limes Arabicus Project 1980-1985. (BAR International Series 340) Archaeopress, Oxford, pp 691-704

Crawford P (2006) The plant remains. In: Parker ST (ed) The Roman frontier in central Jordan. Final report on the Limes Arabicus Project 1980-1989. Dumbarton Oaks, Washington, pp 453-461

D’Alpoim Guedes J, Spengler R (2015) Sampling strategies in paleoethnobotanical analysis. In: Marston JM, d'Alpoim Guedes J, Warinner C (eds) Method and theory in paleoethnobotany. University of Colorado Press, Boulder, pp 77-94

Eichhorn MP, Paris P, Herzog F et al. (2006) Silvoarable systems in Europe - Past, present and future prospects. Agroforest Syst 67:29-50. doi: 10.1007/s10457-005-1111-7 
Fahn A, Werker E, Baas P (1986) Wood anatomy and identification of trees and shrubs from Israel and adjacent regions. Israel Academy of Sciences and Humanities, Jerusalem

Fall P (1990) Deforestation in southern Jordan: Evidence from fossil hyrax middens. In: Bottema S, EntjesNieborg G, Van Zeist W (eds) Man's role in the shaping of the eastern Mediterranean landscape. Balkema, Rotterdam, pp 271-282

Fiema ZT (1996) Nabataean and Palmyrene commerce. The mechanisms of intensification. Les Annales Archéologiques Arabes Syriennes 42:189-195

Fiema ZT (2002) Late-antique Petra and its hinterland: recent research and new interpretations. In: Humphrey J (ed) The Roman and Byzantine Near East 3. J Roman Archaeol, suppl 49:191-252

Fiema ZT (2003) Roman Petra (AD 106-363): A neglected subject. Zeitschrift des Deutschen PalästinaVereins 119:38-58

Fiema ZT, Schmid SSG (2016) Nabataean Basileia and the earthquake of A.D. 363 at Petra: some considerations. Mediterraneo Antico 17/2:419-432

Finné M, Holmgren K, Sundqvist HS et al. (2011) Climate in the eastern Mediterranean, and adjacent regions, during the past 6000 years - A review. J Archaeol Sci 38:3,153-3,173

Frösen J, Arjava A, Lehtinen M (2002) The Petra papyri I. American Center of Oriental Research, Amman Gebel HGK, Bienert H-D, Krämer T et al. (1997) Ba'ja hidden in the Petra mountains: Preliminary report on the 1997 excavations. In: Gebel HGK, Kafafi Z, Rollefson GO (eds) The Prehistory of Jordan, vol 2, Perspectives from 1997. Ex oriente, Berlin, pp 221-262

Gebel HGK, Hermansen BD (2004) Ba'ja 2003: Summary of the 5th season of excavation. Neo-Lithics 2:1518

Geer RM (translator) (1947) Diodorus of Sicily 9 (Books XVIII-XIX). Harvard University Press, Cambridge, Mass

Gentelle P (2009) Aménagement du territoire agricole de la ville de Pétra: la terre et l'eau. In: Mouton M, AlDbiyat M (eds) Stratégies d'acquisition de l'eau et société au Moyen-Orient depuis l'Antiquité. Institut Français d'archéologie du Proche-Orient, Beirut, pp 133-148

Germer R (1985) Flora des pharaonischen Ägypten. Von Zabern, Mainz

Gilliland DR (1986) Paleoethnobotany and paleoenvironment. In: LaBianca S, Lacelle L (eds) Hesban 2. Environmental foundation: Studies of climatical, geological, hydrological, and phytological conditions in Hesban and vicinity. Andrews University Press, Berrien Springs, pp 123-142

Graf D (2007) Nabataeans under Roman rule (after AD 106). In: Politis KD (ed) The world of the Nabataeans, Steiner, Stuttgart, pp 173-186

Graf DF (1990) The origin of the Nabataeans. Aram 2:45-75

Graf DF (2013) Petra and the Nabataeans in the Early Hellenistic period: the literary and archaeological evidence. In: Mouton M, Schmid SSG (eds) Men on the rocks. The formation of Nabataean Petra. Logos, Berlin, pp 35-56

Grawehr M (2010) Petra Ez Zantur IV: Ergebnisse der schweizerisch-liechtensteinischen Ausgrabungen. Eine Bronzewerkstatt des 1. Jhs. n. Chr. von ez Zantur in Petra, Jordanien. Von Zabern, Mainz 
Grawehr M, Keller D (2006) Petra Ez Zantur III: Ergebnisse der schweizerisch-liechtensteinischen Ausgrabungen. Die Gläser aus Petra. Von Zabern, Mainz

Hoppé C (2012) The macroscopic plant remains. In: Politis KD (ed) Excavations at the sanctuary of Lot at Deir 'Ain 'Abata in Jordan, 1988-2003. Jordan Distribution Agency, Amman, pp 518-522

Hunt CO, Gilbertson DD, El-Rishi HA (2007) An 8000-year history of landscape, climate, and copper exploitation in the Middle East: the Wadi Faynan and the Wadi Dana National Reserve in southern Jordan. J Archaeol Sci 34:1,306-1,338. doi: 10.1016/j.jas.2006.10.022

Jacquat C, Martinoli D (1999) Vitis vinifera L.: Wild or cultivated? Study of the grape pips found at Petra, Jordan; 150 B.C. - A.D. 40. Veget Hist Archaeobot 8:25-30

Jones G (1991) Numerical analysis in archaeobotany. In: Behre K-E, Wasylikowa K, Van Zeist W (eds)

Progress in Old World palaeoethnobotany: A retrospective view on the occasion of 20 Years of the international workgroup for palaeoethnobotany. Balkema, Rotterdam, pp 63-80

Jones H (translator) (1961) The geography of Strabo 7 (Books XV-XVI). Harvard University Press, Cambridge, Mass

Karg S (1996) Pflanzenreste aus den nabatäischen und spätrömischen Schichten. In: Bignasca A (ed) Petra. Ez Zantur 1. Ergebnisse der schweizerisch-liechtensteinischen Ausgrabungen 1988-1992. Von Zabern, Mainz, pp 355-358

Kislev ME (1992) Vegetal food of the Bar Kokhba rebels at the Abi'or cave near Jericho. Rev Palaeobot Palynol 73:153-160

Knodell A, Alcock S (2011) Brown University Petra Archaeological Project: The 2010 Petra area and wadi Silaysil survey. Adaj 55:489-508

Koenen L, Kaimio J, Kaimio M, Daniel RW (2013) The Petra papyri II. American Center of Oriental Research, Amman

Kolb B (2007) Nabataean private architecture. In: Politis KD (ed) The world of the Nabataeans. Steiner, Stuttgart, pp 145-172

Kolb B (2003) Petra—From tent to mansion: Living on the terraces of Ez-Zantur. In: Markoe G (ed) Petra rediscovered. Lost city of the Nabataeans. Thames \& Hudson, London, pp 230-237

Kolb B, Keller C (2000) Schweizerisch-liechtensteinische Ausgrabungen auf ez Zantur in Petra 2000. Fondation Suisse-Liechtenstein pour les recherches archéologiques à l'étranger, Basel

Kolb B, Keller D (2001) Swiss-Liechtenstein excavation at az-Zantur/Petra: The Eleventh Season. Adaj 45:311-324

Kouki P (2009) Archaeological evidence of land tenure in the Petra region, Jordan: Nabataean-Early Roman to Late Byzantine. J Mediterr archaeol 22:29-56

Kouki P (2012) The Hinterland of a city: Rural settlement and land use in the Petra region from the Nabataean-Roman to the Early Islamic period. Dissertation, University of Helsinki

Kouki P (2013) The intensification of Nabataean agriculture in the Petra region. In: Mouton M, Schmid SSG (eds) Men on the rocks. The formation of Nabataean Petra. Logos, Berlin, pp 323-334

Lavento M, Siiriäinen A, Jansson H, Kouki P, Mukkala A, Silvonen S, Tenhunen T (2004) The intensive survey around Jabal Harûn: Settlement history and land use in the area. Shaj 8:225-235 
Lavento M, Kouki P, Silvonen S, Ynnilä H, Huotari M (2007) Discussions on terrace cultivation and its relationship to the city of Petra, in southern Jordan. Shaj 9:145-156

Leroy SAG (2010) Pollen analysis of core DS7-1SC (Dead Sea) showing intertwined effects of climatic change and human activities in the Late Holocene. J Archaeol Sci 37:306-316. doi: 10.1016/j.jas.2009.09.042

Lücke B (2008) Demise of the Decapolis. Past and present desertification in the context of soil development, land use, and climate. VDM, Saarbrücken

Marcus R (translator) (1966) Josephus. Jewish antiquities (Books XII-XVI). Harvard University Press, Cambridge, Mass

Margaritis E, Jones M (2006) Beyond cereals: crop processing and Vitis vinifera L. Ethnography, experiment and charred grape remains from Hellenistic Greece. J Archaeol Sci 33:784-805. doi: 16/j.jas.2005.10.021

Marinova E, Van der Valk JMA, Valamoti M, Bretschneider J (2011) An experimental approach for tracing olive processing residues in the archaeobotanical record, with preliminary examples from Tell Tweini, Syria. Veget Hist Archaeobot 20:471-478

Marston JM (2015) Ratios and simple statistics in paleoethnobotanical analysis: data exploration and hypothesis testing. In: Marston JM, d'Alpoim Guedes J, Warinner C (eds) Method and theory in paleoethnobotany. University of Colorado Press, Boulder, pp 163-180

Martinoli D (1997) Étude archéobotanique de macrorestes végétaux d'époques nabatéenne et romaine tardive, Ez-Zantur, Pétra, Jordanie. Dissertation, University of Neuchâtel

Mayerson P (1986) Arid zone farming in Antiquity: A study of ancient agricultural and related hydrological practices in southern Palestine. University Microfilms International, Michigan

McKenzie JS (2005) The architecture of Petra, 2nd edn. Oxbow Books, Oxford

Miller NF, Smart TL (1984) Intentional burning of dung as fuel: a mechanism for the incorporation of charred seeds into the archaeological record. J Ethnobiol 4:15-28

Nasarat M, Danah FA, Naimat S (2012) Agriculture in sixth-century Petra and its hinterland, the evidence from the Petra papyri. Arab Archaeol Epigr 23:105-115. doi: 10.1111/j.1600-0471.2011.00346.x

Neef R (1987) Botanical remains. In: Killick A (ed) Udhruh, caravan city and desert oasis. Romsey, Hampshire, p 16

Neef R (1990) Introduction, development and environmental implications of olive culture : the evidence from Jordan. In: Bottema S, Entjes-Nieborg P, Van Zeist W (eds) Man's role in the shaping of the eastern Mediterranean landscape. Balkema, Rotterdam, pp 295-306

Nefzaoui A (1988) Contribution à la rentabilité de l'oléiculture par une valorisation optimale des sousproduits. In: Allaya M (ed) L'économie de l'olivier. CIHEAM, Paris, pp 153-173

Netzer E (2003) Nabatäische Architektur, insbesondere Gräber und Tempel. Von Zabern, Mainz

Neumann K, Schoch W, Détienne P, Schweingruber FH (2001) Woods of the Sahara and the Sahel: an anatomical atlas. Haupt, Bern

Neumann FH, Kagan EJ, Leroy SAG, Baruch U (2010) Vegetation history and climate fluctuations on a transect along the Dead Sea west shore and their impact on past societies over the last 3500 years. J Arid Environ 74:756-764. doi: 10.1016/j.jaridenv.2009.04.015

Oleson J (1995) The origins and design of Nabataean water-supply systems. Shaj 5:707-719 
Ortloff CR (2005) The water supply and distribution system of the Nabataean city of Petra (Jordan), 300 BCAD 300. Camb Archaeol J 15:93-109. doi: 10.1017/S0959774305000053

Palmer C (2001) Traditional agriculture. In: MacDonald B, Adams R, Bienkowski P (eds) The archaeology of Jordan. Sheffield Academic Press, Sheffield, pp 621-629

R Core Team (2015) R: A language and environment for statistical computing. R foundation for statistical Computing, Vienna. https://www.R-project.org/

Rambeau CMC (2010) Palaeoenvironmental reconstruction in the southern Levant: synthesis, challenges, recent developments and perspectives. Philos T R Soc A 368:5,225-5,248. doi: 10.1098/rsta.2010.0190

Ramsay J (2010) Trade or trash: an examination of the archaeobotanical remains from the Byzantine harbour at Caesarea Maritima, Israel. The International Journal of Nautical Archaeology 39:376-382

Ramsay J (2013) Plant remains. In: Oleson JP, Schick R (eds) Humayma Excavation Project 2. Nabataean campground and necropolis Byzantine churches, and Early Islamic domestic structures. American Schools of Oriental Research, Boston, pp 351-380

Ramsay J, Bedal L-A (2015) Garden variety seeds? Botanical remains from the Petra Garden and Pool Complex. Veget Hist Archaeobot 24:621-634. doi: 10.1007/s00334-015-0520-4

Ramsay J, Smith II AM (2013) Desert agriculture at Bir Madhkur: The first archaeobotanical evidence to support the timing and scale of agriculture in the hinterland of Petra. J Arid Environ 99:51-63

Renel F, Mouton M (2013) The architectural remains and pottery assemblage from the early phases at the Qasr al-Bint. In: Mouton M, Schmid SSG (eds) Men on the rocks. The formation of Nabataean Petra. Logos, Berlin, pp 57-78

Renel F, Mouton M, Augé C et al. (2012) Dating the early phases under the temenos of the Qasr al-Bint at Petra. Supplement to Proceedings of the Seminar for Arabian Studies 42:1-16

Ruben I (2006) Field guide to the plants and animals of Petra. Petra National Trust, Amman

Russell KW (1995) Traditional Bedouin agriculture at Petra: Ethnoarchaeological insights into the evolution of food production. Shaj 5:695-696

Ryzewski K, Sheldon BW, Alcock SE et al. (2011) Multiple assessments of local properties, production, and performance in metal objects: an experimental case study from Petra, Jordan. Archaeol Anthropol Sci 3:173184. doi: 10.1007/s12520-011-0051-6

Sachet I, Delhopital N, Bouchaud C, Tomé Carpentier C (2013) The Hellenistic-Nabataean crypt in tower tomb 303 at ath-Thughrah in Petra. Results of the archaeological and multi-disciplinary studies. Annual of the Department of Antiquities of Jordan 57:141-166

Schmid SSG (2000) Die Feinkeramik der Nabatäer. Typologie, Chronologie und kulturhistorische Hintergründe. In: Schmid SSG, Kolb B (eds) Petra - Ez Zantur II. Ergebnisse der schweizerischliechtensteinischen Ausgrabungen. Von Zabern, Mainz, pp 1-199

Schmid SSG (2001) The Nabataeans: travellers between lifestyles. In: MacDonald B, Adams R, Bienkowski

P (eds) The archaeology of Jordan. Sheffield Academic Press, Sheffield, pp 367-426

Schmid SSG, Kolb B (2000) Petra - Ez Zantur II: Ergebnisse der schweizerisch-liechtensteinischen Ausgrabungen. Von Zabern, Mainz 
Schmid SSG, Bienkowski P, Fiema ZT, Kolb B (2012) The palaces of the Nabataean kings at Petra. In: Nehmé L, Wadeson L (eds) The Nabataeans in focus: Current archaeological research at Petra. Archaeopress, Oxford

Schweingruber FH (1990) Anatomy of European wood: an atlas for the identification of European trees, shrubs and dwarf shrubs. Haupt, Bern

Simchoni O, Kislev ME (2009) Relict plant remains in the "Caves of the Spear”. Israel Explor J 59:47-62

Simms SR, Russell KW (1997) Bedouin hand harvesting of wheat and barley: Implications for early cultivation in southwestern Asia. Curr Anthropol 38:696-702

Stucky R (1995) The Nabataean house and the urbanistic system of the habitation quarters in Petra. Shaj 5:193-198

Studer J (2002) City and monastery: animals raised and consumed in the Petra area. In: Frösen J, Fiema ZT (eds) Petra: a city forgotten and rediscovered. University Press, Helsinki, pp 167-172

Studer J (2007) Animal exploitation in the Nabataean world. In: Politis KD (ed) The world of the Nabataeans. Steiner, Stuttgart, pp 251-272

Studer J, Schneider A (2008) Camel use in the Petra region, Jordan: 1st century BC to 4th century AD. In: Vila E, Gourichon L, Choyke AM, Buitenhuis H (eds) Archaeozoology of the Near East VIII. Maison de l’Orient et de la Méditerranée, Lyon, pp 581-596

Tengberg M (2012) Beginnings and early history of date palm garden cultivation in the Middle East. J Arid Environ 86:139-147. doi: 10.1016/j.jaridenv.2011.11.022

Thackeray H (translator) (1967) Josephus. The Jewish war (Books I-II). Harvard University Press, Cambridge, Mass

Thanheiser U (2002) Roman agriculture and gardening in Egypt as seen from Kellis. In: Hope CA, Bowen GE (eds) Dakhleh oasis project: preliminary reports on the 1994-1995 to 1998-1999 field Seasons. Oxbow, Oxford, pp 299-310

Théry-Parisot I, Chabal L, Chrzavzez J (2010) Anthracology and taphonomy, from wood gathering to charcoal analysis. A review of the taphonomic processes modifying charcoal assemblages, in archaeological contexts. Palaeogeogr Palaeoecol 291:142-153

Tholbecq L (2013) The hinterland of Petra (Jordan) and the Jabal Shara during the Nabataean, Roman and Byzantine periods. In: Mouton M, Schmid SSG (eds) Men on the rocks. The formation of Nabataean Petra. Logos, Berlin, pp 295-312

Tholbecq L, Durand C (2013) A late second-century BC Nabataean occupation at Jabal Numayr: the earliest phase of the "Obodas Chapel” sanctuary. In: Mouton M, Schmid SSG (eds) Men on the rocks. The formation of Nabataean Petra. Logos, Berlin, pp 205-222

Tholbecq L, Durand C, Bouchaud C (2008) A Nabataean rock-cut sanctuary in Petra: second preliminary report on the "Obodas chapel" excavation project, Jabal Numayr (2005-2007). Adaj 52:235-254

Van der Veen M (1999) The economic value of chaff and straw in arid and temperate zones. Veget Hist Archaeobot 8:211-224. doi: 10.1007/BF02342721

Van der Veen M (2011) Consumption, trade and innovation: Exploring the botanical remains from the Roman and Islamic Ports at Quseir al-Qadim, Egypt. Africa Magna Verlag, Frankfurt 
Warnock P (2007) Identification of ancient olive oil processing methods based on olive remains. (BAR International Series 1635) Archaeopress, Oxford

Wenning R (2007) The Nabataeans in History. In: Politis KD (ed) The world of the Nabataeans. Steiner, Stuttgart, pp 25-44

Willcox G (1992) Archaeobotanical investigations at Pella (1983). In: McNicoll T (ed) Pella in Jordan. Australian National Gallery, Sydney, pp 253-256

Willcox G (2003) L'économie végétale à Bosra et à Si': résultats d'analyse de restes végétaux carbonisés des périodes romaine, byzantine et islamique. In: Dentzer-Feydy J, Dentzer JM, Blanc P-M (eds) Hauran II. Institut français d'archéologie du Proche-Orient, Beirut, pp 177-184

Zabaniotou AA, Kalogiannis G, Kappas E, Karabelas AJ (2000) Olive residues (cuttings and kernels) rapid pyrolysis product yields and kinetics. Biomass Bioenerg 18:411-420. doi: 10.1016/S0961-9534(00)00002-7

Zaitschek DV (1962) Remains of plants from the Cave of the Pool. Israel Explor J 12:184-185

Zeitler JP (1990) Houses, sherds and bones: Aspects of daily life in Petra. In: Kermer S (ed) The Near East in Antiquity: German contributions to the archaeology of Jordan, Palestine, Syria, Lebanon and Egypt, vol 1. Goethe-Institut, Amman, pp 39-51

Zeitler JP (1991) Gebäude, Gewerbe und Geschirr. In: Lindner M, Zeitler JP (eds) Petra, Königin der Weihrauchstraße. VKA-Verlag, Fürth, pp 71-78

Zeitler JP (1993) Excavations and surveys in Petra 1989-1990. Syria 70:255-260

Zohary D, Hopf M, Weiss E (2012) Domestication of plants in the Old World: The origin and spread of domesticated plants in Southwest Asia, Europe, and the Mediterranean Basin, $4^{\text {th }}$ ed. Oxford University Press, Oxford

Zohary M (1973) Geobotanical foundations of the Middle East. Fischer, Stuttgart

\section{Figure Captions}

Fig. 1 Geographical settings: Top left, Location of Petra and the main archaeological sites cited in the text, from Google Maps. Top right, Aerial photograph of the ez-Zantur area, Petra, with the four excavated terraces, from Swiss-Liechtenstein Archaeological Mission. Bottom, Schematic map of Petra, location of ez-Zantur, after a map drawing by I. Sachet

Fig. 2 Schematic profile of the modern relationships between geology, topography, vegetation and climate from the western wadi Arabah to the eastern Jordanian upland and the potential origin of the main identified archaeological taxa; adapted from Beckers et al. (2013), Besançon (2010), Hunt et al. (2007) 
Fig. 3 Carpological diagram, ez-Zantur, Petra. Relative abundance of minimum number of items and ubiquity proportion of the potentially cultivated plants per area and period. Abbreviations, ENab, Early Nabataean; Nab, Nabataean; Rom, Roman; LRom, Late Roman; Byz, Byzantine. For quantitative details, see Tables 1, 2, 3

Fig. 4 Carpological diagram, ez-Zantur, Petra. Relative abundance of minimum number of items and ubiquity proportion of the various categories of cultivated plants per area and period.

Abbreviations, ENab, Early Nabataean; Nab, Nabataean; Rom Roman; LRom Late Roman; Byz, Byzantine; n, Number of samples; MNI, Minimum number of items

Table 1 Quantitative data according to the different types of plant remains per period and terrace at ez-Zantur. Abbreviations, ENab, Early Nabataean; Nab, Classical Nabataean; Rom, Roman; LRom, Late Roman; Byz, Byzantine

Table 2 Carpological data from ez-Zantur, Petra, total number of remains (NR) and ubiquity (Ub, number of samples where the taxon is present); Abbreviations, ac, achene; end endocarp; fgt, fragment; gl, lemma/palea fragment; mer, mericarp; ped; pedicel; k, kernel; nut, nutlet; rac, rachis fragment; s, seed; sf, spikelet fork. For chronology and further abbreviations, see Table 1

Table 3 Carpological data from ez-Zantur, Petra, minimum number of items (MNI) and minimal number of items weighted by volume (MNIw) per period and terrace; for chronology and further abbreviations, see Table 1

Table 4 Distribution of the wild plants found in Ez III during the Nabataean period (Nab) and Ez IV during the Late Roman period (LRom) according to modern weed communities and life cycles (Zohary 1973). a, annual; b, biennual; p, perennial. The doubtful taxa (cf.) are excluded

Table 5 Charcoal results of ez-Zantur, Petra. ENab, Early Nabataean; Nab, Classical Nabataean; LRom, Late Roman; NR, Number of remains; Ub, Ubiquity; C.I., precision of the Confidence Interval (95\%)

Table 6 Taxa identified through carpological and wood charcoal analyses. ENab, Early Nabataean; Nab, Nabataean; LRom, Late Roman; c, carpological results; a, anthracological results

Table 7 Distribution of the main cultivated plants from several archaeological sites in the Petra region, according to the estimation of the minimum number of plant macro-remains proportions recovered. $\mathrm{x}$, present; $\mathrm{xxx}$, abundant; + , no available quantitative data 


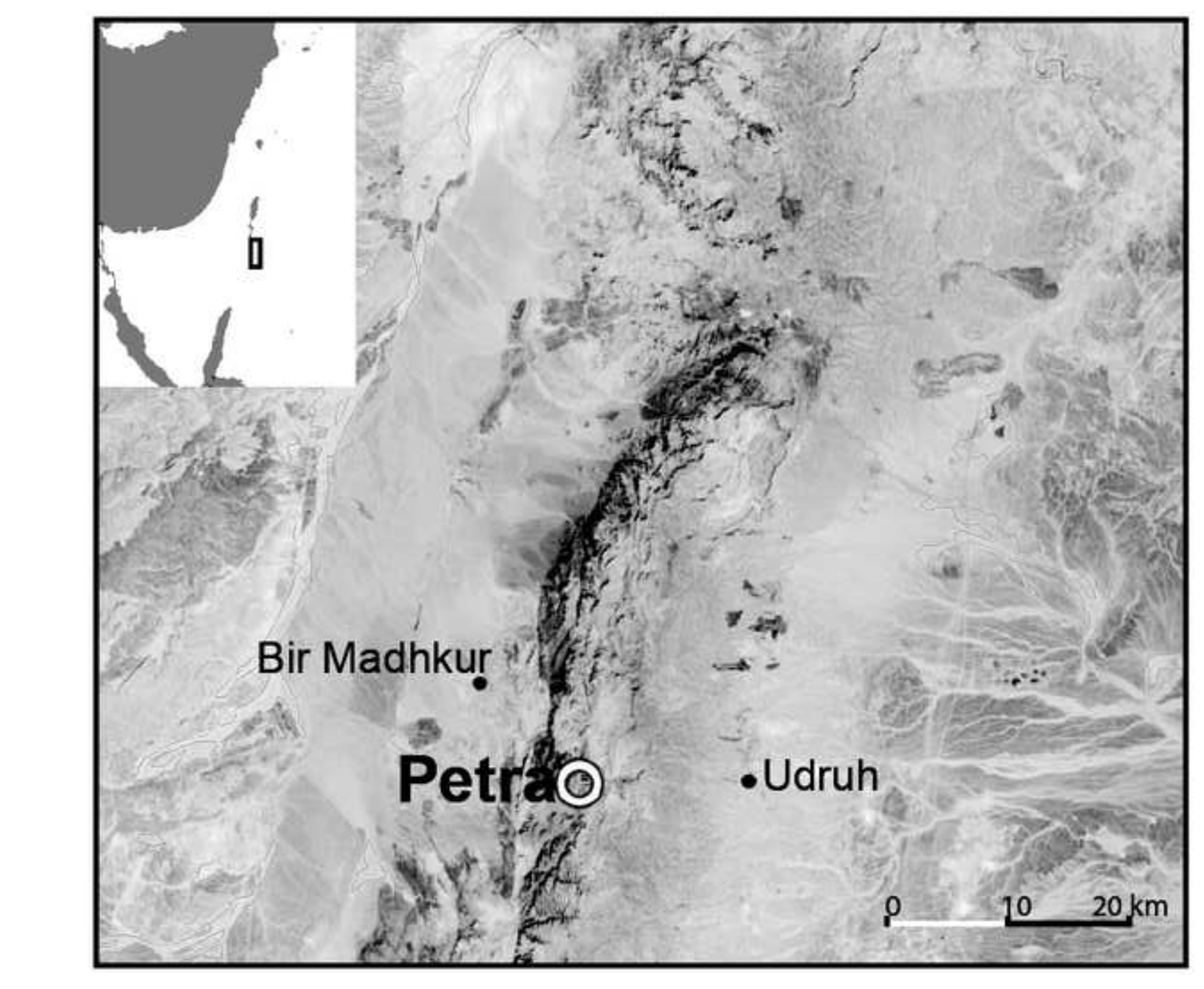

.




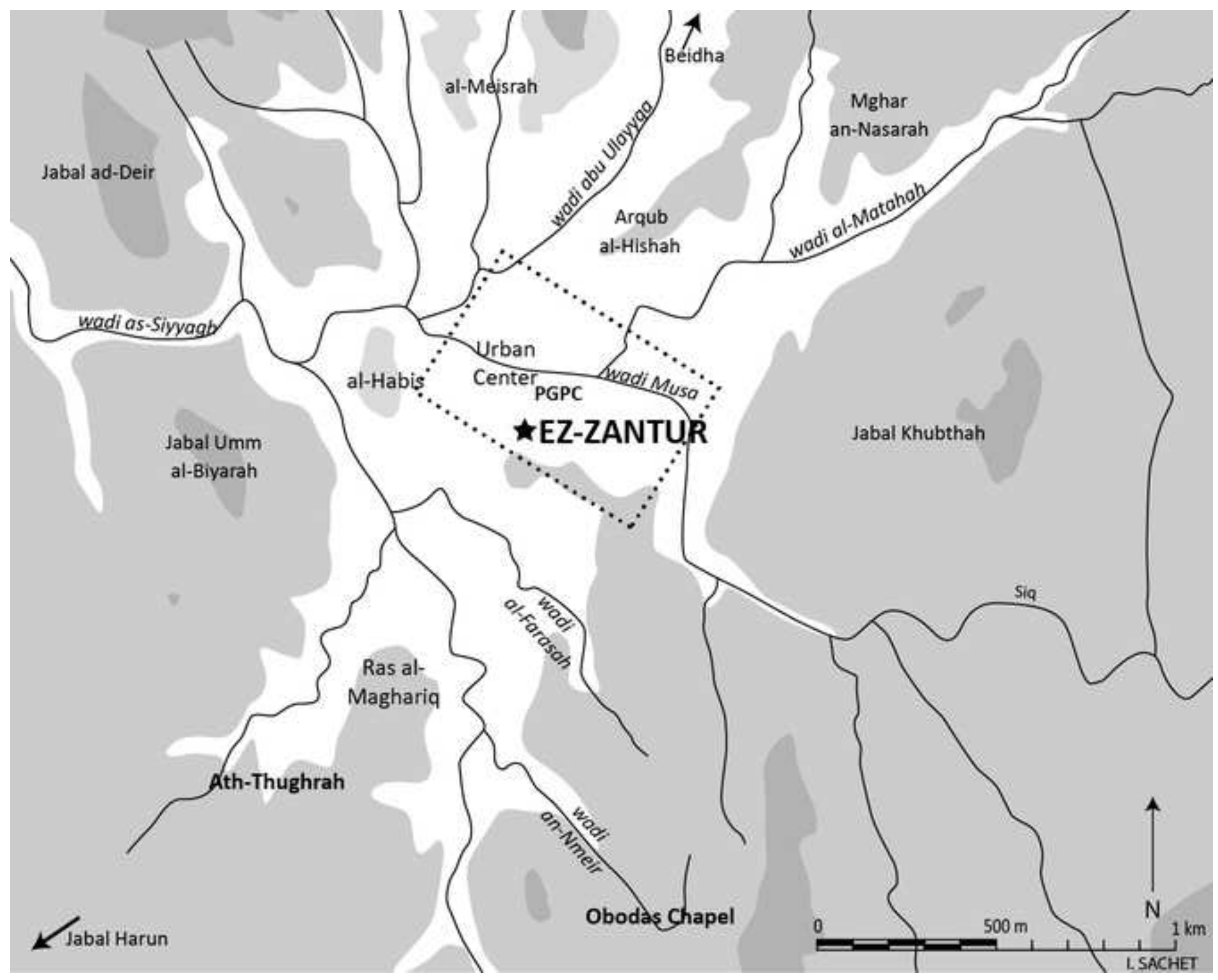




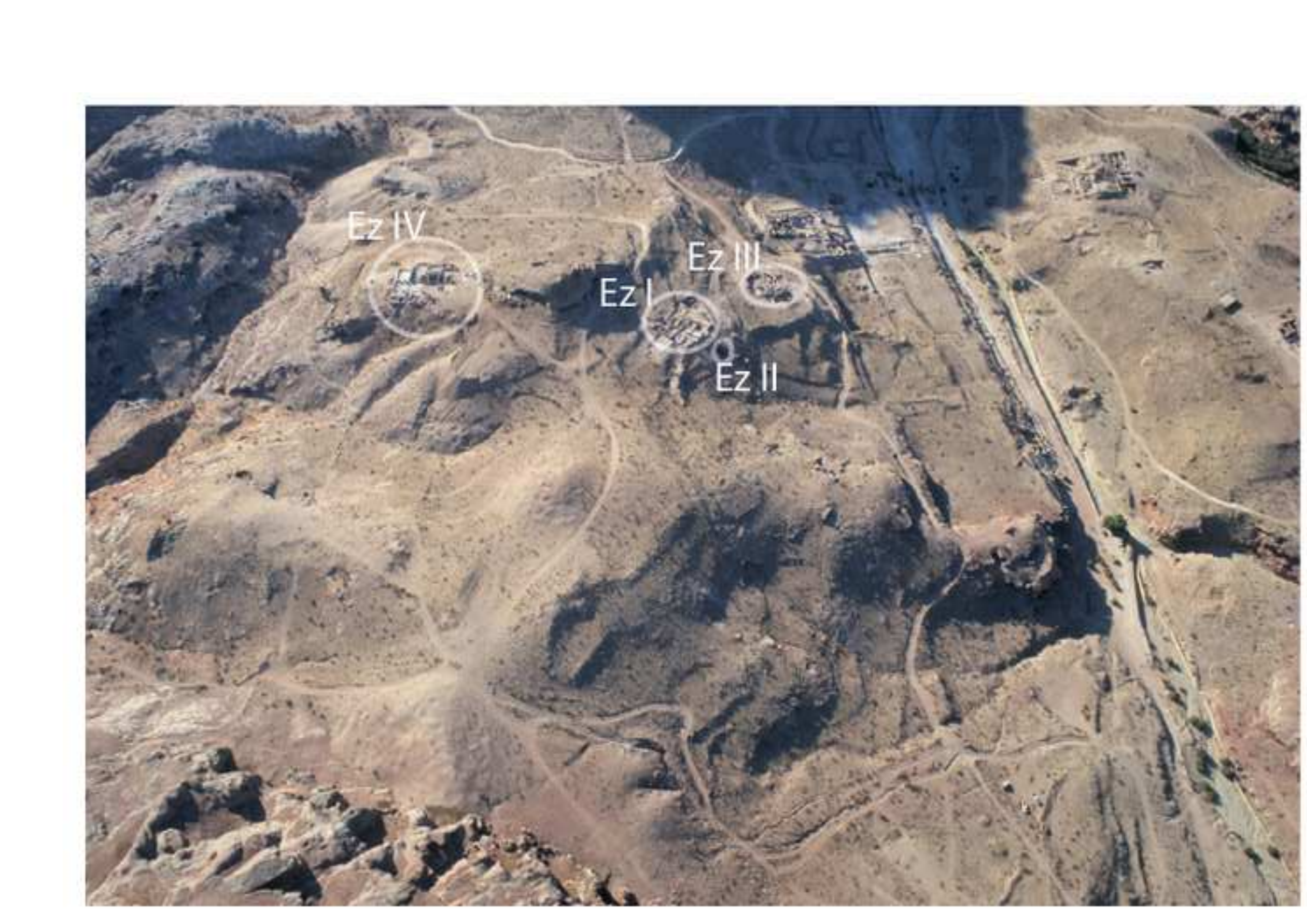




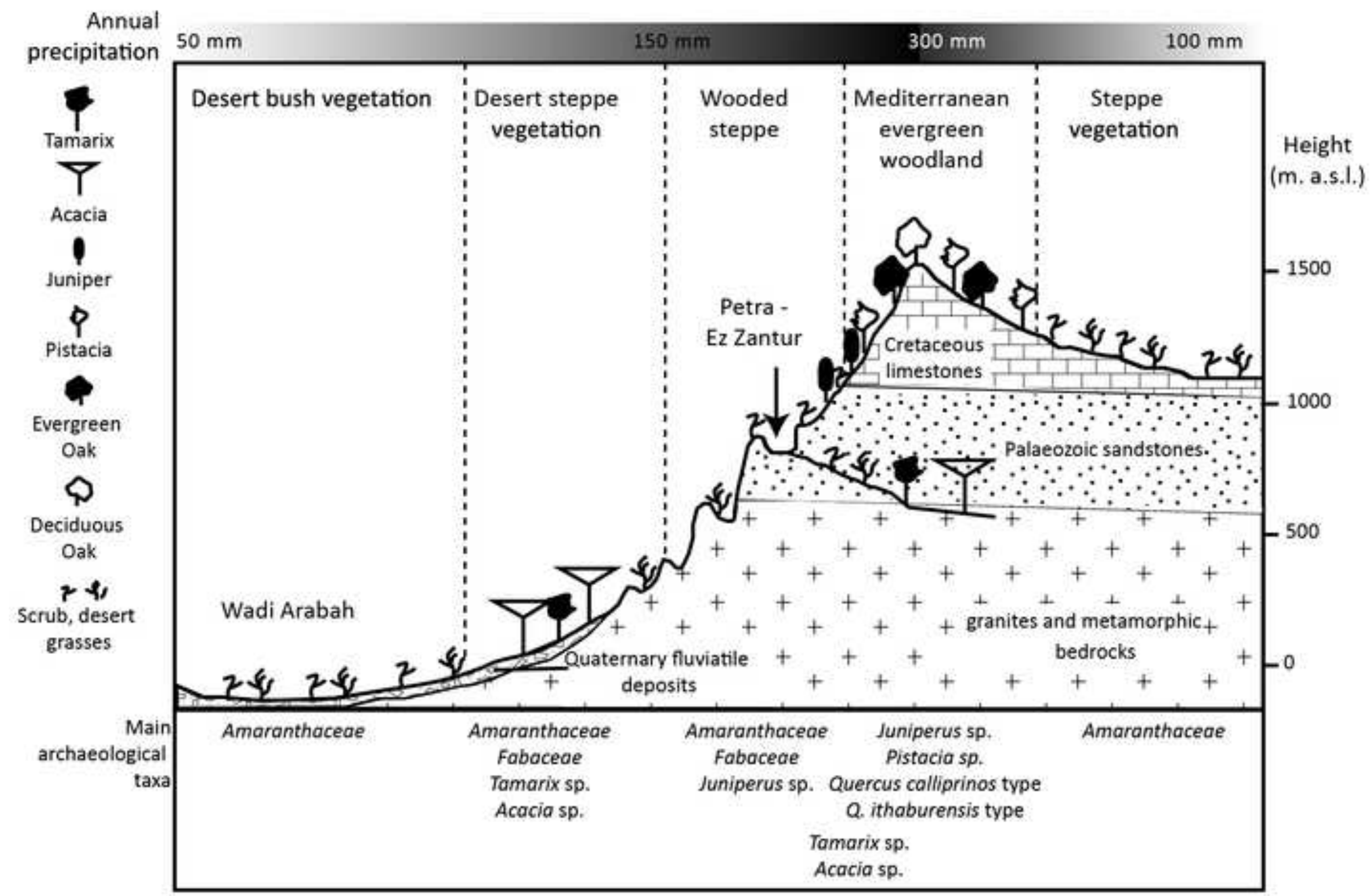




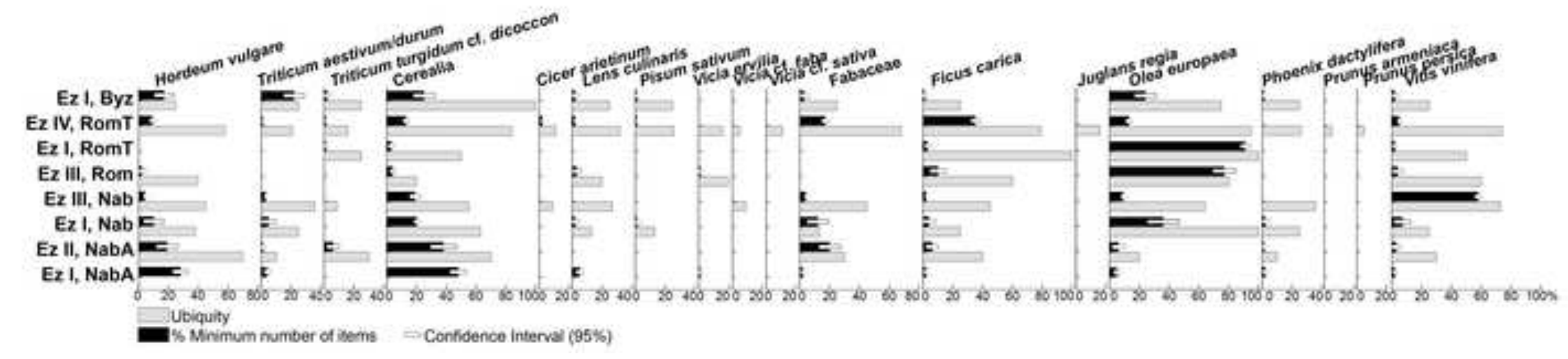




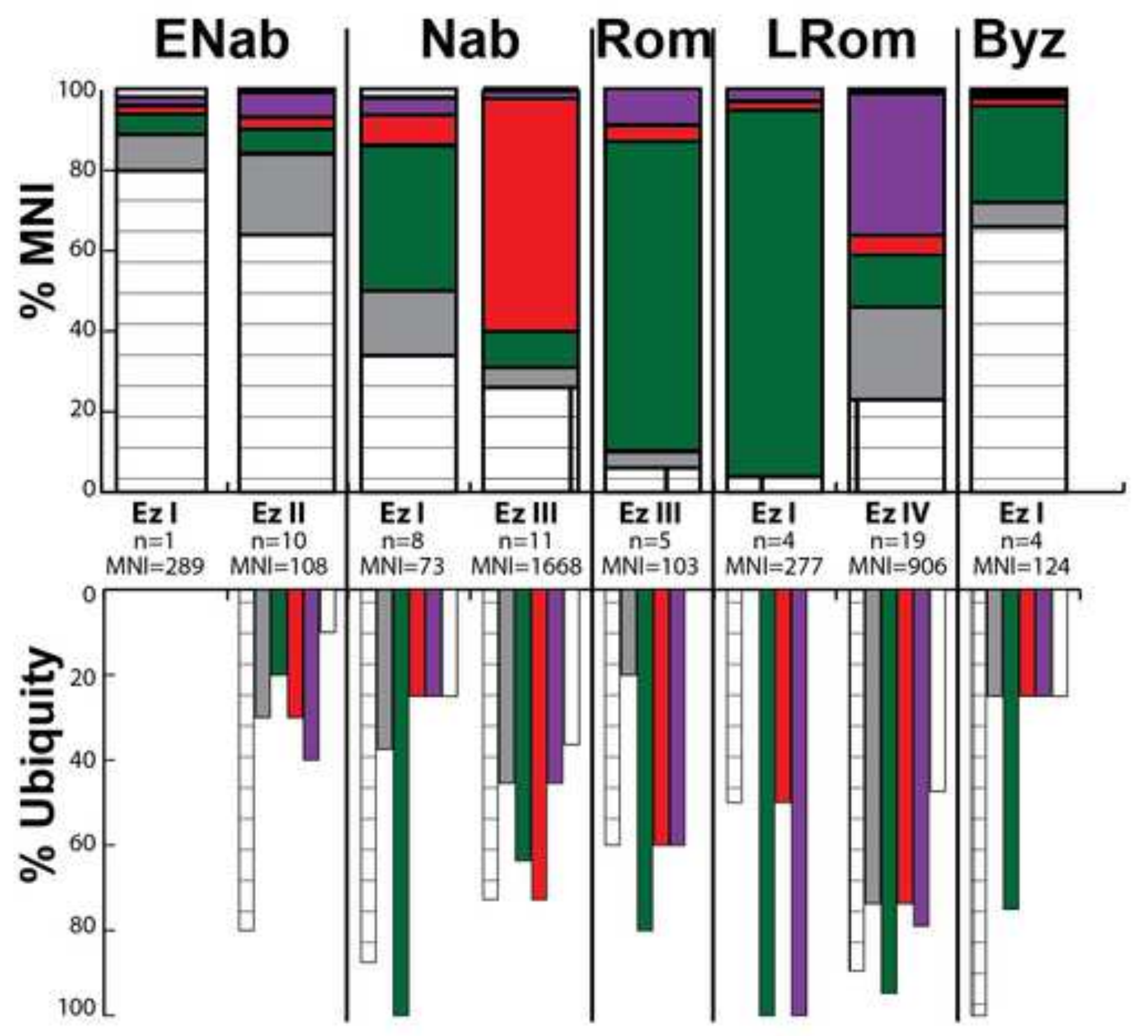

\section{Other fruits} Fig

Grape

Olive

$\square$ Pulses

$\boxplus$ Cereals 
Table 1. Quantitative data according to the different types of plant remains per period and terrace at ez-Zantur. $\mathrm{ENab}=$ Early Nabataean, Nab=Classical Nabataean, Rom=Roman, LRom=Late Roman, Byz=Byzantine

\begin{tabular}{|c|c|c|c|c|c|c|c|c|c|}
\hline & Phase & \multicolumn{2}{|c|}{$\mathrm{ENab}$} & \multicolumn{2}{|c|}{$\mathrm{Nab}$} & Rom & \multicolumn{2}{|c|}{ LRom } & Byz \\
\hline & Dating & \multicolumn{2}{|c|}{$\begin{array}{c}\operatorname{mid} 2^{\text {nd }} \text { c.-mid } \\
1^{\text {st }} \text { c. BC }\end{array}$} & \multicolumn{2}{|c|}{$\begin{array}{c}\operatorname{mid} 1^{\text {st }} \text { c. BC- } \\
1^{\text {st }} \text { c. AD }\end{array}$} & $\begin{array}{l}2^{\text {nd }} \\
3^{\text {rd }} c .\end{array}$ & \multicolumn{2}{|c|}{$1^{\text {st }}$ half $4^{\text {th }} c$. } & $\begin{array}{l}\text { Early } \\
5^{\text {th }} \mathrm{c} .\end{array}$ \\
\hline & Terrace & Ez I & Ez II & Ez I & Ez III & Ez III & Ez I & Ez IV & Ez I \\
\hline \multirow{4}{*}{$\begin{array}{l}\text { Carpological } \\
\text { remains }\end{array}$} & $\mathrm{Nb}$ of samples & 1 & 10 & 8 & 11 & 5 & 4 & 19 & 4 \\
\hline & Volume (l) & 22 & 40.5 & 63 & 179.2 & 41.9 & 18.5 & 352.7 & 25 \\
\hline & Raw $\mathrm{Nb}$ of remains & 352 & 144 & 160 & 2961 & 345 & 1001 & 2404 & 273 \\
\hline & $\begin{array}{l}\text { Minimum number } \\
\text { of items (MNI) }\end{array}$ & 295 & 119 & 81 & 1883 & 114 & 283 & 1989 & 177 \\
\hline \multirow{3}{*}{ Charcoal } & $\mathrm{Nb}$ of samples & 5 & 5 & 6 & 3 & - & - & 15 & - \\
\hline & Volume (l) & 22 & 21.6 & 23.4 & 5.4 & - & - & 208.1 & - \\
\hline & $\mathrm{Nb}$ of remains & 21 & 22 & 101 & 41 & - & - & 439 & - \\
\hline
\end{tabular}


Table 2. Carpological data from ez-Zantur, Petra, raw number of remains (NR) and ubiquity (Ub). ENab= Early Nabataean, Nab=Classical Nabataean, Rom=Roman, LRom=Late Roman, Byz=Byzantine, ac=achene, end=endocarp, fgt=fragment, gl=lemma/palea fragment, mer=mericarp, ped=pedicel, k=kernel, nut=nutlet, rac.=rachis fragment, $\mathrm{s}=$ seed, $\mathrm{sf}=$ spikelet fork

\begin{tabular}{|c|c|c|c|c|c|c|c|c|c|c|c|c|c|c|c|}
\hline Phase & \multicolumn{3}{|c|}{ ENab } & \multicolumn{4}{|c|}{$\mathrm{Nab}$} & \multicolumn{2}{|c|}{ Rom } & \multicolumn{4}{|c|}{ LRom } & \multicolumn{2}{|c|}{ Byz } \\
\hline Dating & \multicolumn{3}{|c|}{$\begin{array}{c}\operatorname{mid} 2^{\text {nd }} \mathrm{c} .-\mathrm{mid} 1^{\text {st }} \mathrm{c} . \\
\text { BC }\end{array}$} & \multicolumn{4}{|c|}{$\operatorname{mid} 1^{\text {st }}$ c. BC-1 $1^{\text {st }}$ c. AD } & \multicolumn{2}{|c|}{$2^{\text {nd }}-3^{\text {rd }} c$} & \multicolumn{4}{|c|}{$1^{\text {st }}$ half $4^{\text {th }} \mathrm{c}$. } & \multicolumn{2}{|c|}{ Early $5^{\text {th }} \mathrm{c}$} \\
\hline Terrace & Ez I & \multicolumn{2}{|c|}{ Ez II } & \multicolumn{2}{|c|}{ Ez I } & \multicolumn{2}{|c|}{ Ez III } & \multicolumn{2}{|c|}{ Ez III } & \multicolumn{2}{|c|}{ Ez I } & \multicolumn{2}{|c|}{ Ez IV } & \multicolumn{2}{|c|}{ Ez I } \\
\hline Number of samples & 1 & \multicolumn{2}{|c|}{10} & \multicolumn{2}{|c|}{8} & \multicolumn{2}{|c|}{11} & \multicolumn{2}{|c|}{5} & \multicolumn{2}{|c|}{4} & \multicolumn{2}{|c|}{19} & \multicolumn{2}{|c|}{4} \\
\hline \multirow[t]{2}{*}{ Volume (litres) } & 22 & \multicolumn{2}{|c|}{40.5} & & & & & & & & & & & & \\
\hline & NR & NR & $\mathrm{Ub}$ & NR & $\mathrm{Ub}$ & NR & $\mathrm{Ub}$ & NR & $\mathrm{Ub}$ & NR & $\mathrm{Ub}$ & NR & $\mathrm{Ub}$ & NR & $\mathrm{Ub}$ \\
\hline Cereals, grains & & & & & & & & & & & & & & & \\
\hline Hordeum vulgare & 80 & 24 & 8 & 8 & 3 & 51 & 8 & 2 & 2 & & & 82 & 11 & 21 & 2 \\
\hline Triticum.aestivum/durum & 11 & & & 4 & 2 & 26 & 1 & & & & & & & 23 & 1 \\
\hline Triticum sp. & & 2 & 1 & & & 4 & 2 & & & & & 9 & 4 & 7 & 1 \\
\hline Cerealia & 140 & 44 & 7 & 16 & 5 & 291 & 6 & 4 & 1 & 7 & 2 & 134 & 16 & 31 & 4 \\
\hline Cereals, chaff and straw & & & & & & & & & & & & & & & \\
\hline Hordeum vulgare, rac & & & & & & 5 & 1 & & & & & 4 & 3 & & \\
\hline Triticum aestivum/durum, rac & & & & & & 9 & 2 & & & & & 1 & 1 & & \\
\hline Triticum turgidum subsp. dicoccon, rac & & 3 & 2 & & & & & & & 1 & 1 & 1 & 1 & & \\
\hline Cerealia, rac & & 2 & 2 & & & 17 & 1 & & & 1 & 1 & 3 & 1 & & \\
\hline Cerealia, gl & & 1 & 1 & & & & & & & & & 2 & 1 & & \\
\hline Cerealia, culm node & & 3 & 3 & 2 & 1 & 2 & 2 & & & & & 1 & 1 & & \\
\hline Cerealia, root-culm & 1 & & & & & & & & & & & & & & \\
\hline Pulses, seeds & & & & & & & & & & & & & & & \\
\hline Cicer arietinum & & & & & & 5 & 1 & & & & & 2 & 2 & & \\
\hline Lens culinaris & 15 & & & 2 & 1 & 4 & 3 & 3 & 1 & & & 23 & 6 & 2 & 1 \\
\hline Pisum sativum & 1 & & & 1 & 1 & & & & & & & 8 & 5 & 1 & 1 \\
\hline Vicia ervilia & 3 & & & & & & & 1 & 1 & & & 5 & 3 & & \\
\hline Vicia cf. faba & & & & & & 1 & 1 & & & & & 1 & 1 & & \\
\hline Vicia cf. sativa & & & & & & & & & & & & 3 & 2 & & \\
\hline Fabaceae & 6 & 7 & 3 & 1 & 1 & 13 & 5 & & & & & 56 & 13 & 4 & 1 \\
\hline Potential cultivated fruit trees & & & & & & & & & & & & & & & \\
\hline Ficus cf. carica, ac & 6 & 8 & 4 & 3 & 2 & 37 & 5 & 10 & 3 & 9 & 4 & 364 & 15 & 1 & 1 \\
\hline Juglans regia, end & & & & & & & & & & & & 3 & 3 & & \\
\hline Olea europaea, end (whole) & 3 & & & 4 & 2 & 2 & 2 & 2 & 1 & 12 & 2 & 4 & 4 & 2 & 1 \\
\hline
\end{tabular}




\begin{tabular}{|c|c|c|c|c|c|c|c|c|c|c|c|c|c|c|c|}
\hline Olea europaea, end (fgt) & 48 & 29 & 2 & 102 & 7 & 599 & 6 & 308 & 4 & 955 & 4 & 524 & 18 & 112 & 3 \\
\hline Olea europaea, $\mathrm{k}$ & 1 & & & 1 & 1 & 9 & 4 & & & & & 2 & 2 & 11 & 2 \\
\hline Phoenix dactylifera, $\mathrm{s}$ (fgt) & 24 & 4 & 1 & 4 & 2 & 8 & 4 & & & & & 8 & 5 & 1 & 1 \\
\hline Prunus armeniaca, end & & & & & & & & & & & & 1 & 1 & & \\
\hline Prunus persica, end & & & & & & & & & & & & 2 & 1 & & \\
\hline Vitis vinifera, $\mathrm{s}$ & 5 & 4 & 3 & 6 & 2 & 800 & 8 & 4 & 3 & 5 & 2 & 47 & 14 & 3 & 1 \\
\hline Vitis vinifera, $\mathrm{s}$ (fgt) & 3 & 1 & 1 & & & 815 & 2 & & & 3 & 1 & 27 & 4 & & \\
\hline Vitis vinifera, ped & & & & & & 5 & 1 & & & & & & & & \\
\hline \multicolumn{16}{|l|}{ Wild plants } \\
\hline Acacia sp., s & & & & & & & & & & & & & & 1 & 1 \\
\hline Amaranthus/Chenopodium, $\mathrm{s}$ & & & & & & 5 & 1 & & & & & & & & \\
\hline Amaranthaceae $\mathrm{s}$ & & & & 1 & 1 & 13 & 2 & & & & & 639 & 6 & & \\
\hline Androsace sp., s & & & & & & & & & & & & 1 & 1 & & \\
\hline cf. Anthemis sp., ac & & & & & & & & & & & & 1 & 1 & & \\
\hline Apiaceae, mer & & & & & & 1 & 1 & & & & & & & & \\
\hline Asperula/Galium, ac & & & & 1 & 1 & 9 & 3 & & & 1 & 1 & 5 & 5 & & \\
\hline Asteraceae, mer & & & & & & 2 & 1 & & & & & 2 & 2 & & \\
\hline Astragalus/Trigonella, $\mathrm{s}$ & & & & & & 17 & 1 & & & & & & & & \\
\hline Boraginaceae, nut & & 1 & 1 & & & 6 & 3 & 2 & 1 & 1 & 1 & 126 & 11 & & \\
\hline Brassicaceae, $\mathrm{s}$ & & & & 1 & 1 & 3 & 2 & & & & & & & & \\
\hline cf. Bromus, car & & & & & & & & & & & & 1 & 1 & & \\
\hline Buplerum sp., ac & & & & & & 1 & 1 & & & & & & & & \\
\hline Capparis type, $\mathrm{s}$ & & & & & & 1 & 1 & & & & & & & & \\
\hline cf. Caucalis sp., s & & & & & & & & & & & & 1 & 1 & & \\
\hline Cerastium sp., s & & & & & & 4 & 1 & & & & & & & & \\
\hline Coronilla sp., s & & & & & & 1 & 1 & & & & & & & & \\
\hline Crataegus sp. end & 1 & & & & & & & & & & & & & & \\
\hline Cynodon dactylon, $\mathrm{s}$ & & 2 & 1 & & & & & & & & & & & & \\
\hline Cyperaceae / Polygonaceae, $\mathrm{s}$ & & & & & & 1 & 1 & & & & & 2 & 2 & & \\
\hline Erodium sp., awn & & & & & & 5 & 1 & & & & & 1 & 1 & & \\
\hline Euphorbia cf. aleppica, $\mathrm{s}$ & & & & & & & & & & & & 4 & 1 & & \\
\hline Fabaceae, $\mathrm{s}$ & & & & & & 1 & 1 & & & & & 4 & 1 & & \\
\hline Fumaria sp., s & & & & & & 2 & 1 & 1 & 1 & & & 7 & 4 & & \\
\hline Heliotropium sp., nut & & & & & & & & & & & & 1 & 1 & 1 & 1 \\
\hline Hordeum cf. spontaneum, car & & & & & & 6 & 1 & & & & & & & & \\
\hline Hyoscyamus sp., s & & & & & & & & & & 1 & 1 & & & & \\
\hline
\end{tabular}




\begin{tabular}{|c|c|c|c|c|c|c|c|c|c|c|c|c|c|c|c|}
\hline Labiateae, $\mathrm{s}$ & & & & & & 3 & 2 & & & & & 2 & 2 & & \\
\hline Liliaceae, $\mathrm{s}$ & & 3 & 1 & & & 1 & 1 & & & & & & & & \\
\hline Lolium temulentum, car & & & & & & 1 & 1 & & & & & & & 1 & 1 \\
\hline Lolium sp., car & & & & & & 10 & 1 & & & & & & & & \\
\hline Malva cf. parviflora, mer & & & & & & 55 & 1 & & & 1 & 1 & & & & \\
\hline Malva sp., s & & & & & & 3 & 1 & & & & & 8 & 3 & & \\
\hline Medicago sp., s & & & & & & 27 & 1 & & & & & 10 & 6 & & \\
\hline Melilotus/Trifolium, $\mathrm{s}$ & & & & & & 1 & 1 & 1 & 1 & & & 11 & 6 & & \\
\hline Onopordum sp., ach & & & & & & & & & & & & 1 & 1 & & \\
\hline Panicum / Setaria, car & & & & & & 2 & 2 & & & & & 3 & 3 & & \\
\hline Papaver sp., s & & & & & & 2 & 1 & & & & & & & & \\
\hline Phalaris sp., car & & & & & & & & & & & & 52 & 2 & & \\
\hline Poaceae, car & & & & & & 4 & 1 & & & & & 44 & 8 & & \\
\hline Poaceae, sf & & & & & & & & & & & & 11 & 1 & & \\
\hline Pistacia sp., end & 4 & & & 1 & 1 & 1 & 1 & & & & & & & & \\
\hline Plantago cf. lanceolata, $\mathrm{s}$ & & & & & & 3 & 1 & & & & & 2 & 2 & & \\
\hline Polygonum/Rumex, s & & & & & & & & & & 1 & 1 & 3 & 1 & & \\
\hline Silene sp., s & & 1 & 1 & 1 & 1 & 50 & 2 & 5 & 2 & & & 74 & 12 & & \\
\hline cf. Solanum sp., s & & & & & & 2 & 1 & & & & & & & & \\
\hline cf. Stellaria sp., s & & 4 & 1 & & & 1 & 1 & & & & & 1 & 1 & & \\
\hline Viola sp., s & & & & & & 1 & 1 & & & & & & & & \\
\hline Indeterminate & & 1 & 1 & 1 & 1 & 13 & 3 & 2 & 1 & 3 & 1 & 70 & 10 & 51 & 2 \\
\hline Sum & 352 & 144 & & 160 & & 2961 & & 345 & & 1001 & & 2404 & & 273 & \\
\hline Sheep/goat faeces & & 25 & 2 & 9 & 2 & 1 & 1 & & & 4 & 1 & & & & \\
\hline
\end{tabular}


Table 3. Carpological data from ez-Zantur, Petra, Minimum number of items weighted by volume per period and terrace. $\mathrm{ENab}=$ Early Nabataean, Nab=Classical Nabataean, Rom=Roman, LRom=Late Roman, Byz=Byzantine

\begin{tabular}{|c|c|c|c|c|c|c|c|c|}
\hline Phase & \multicolumn{2}{|c|}{ ENab } & \multicolumn{2}{|c|}{$\mathrm{Nab}$} & Rom & \multicolumn{2}{|c|}{ LRom } & Byz \\
\hline Dating & $\begin{array}{r}\operatorname{mid} 2 \\
1^{\text {st }}\end{array}$ & $\begin{array}{l}- \text {-mid } \\
3 \mathrm{C}\end{array}$ & mid 1 & $\begin{array}{l}\text { BC- } 1^{\text {st }} \\
\text { D }\end{array}$ & $\begin{array}{c}2^{\text {nd }}-3^{\text {rd }} \\
\text { c. }\end{array}$ & $1^{\text {st }} \mathrm{h}$ & $4^{\text {th }} \mathrm{c}$. & $\begin{array}{l}\text { Early } \\
5^{\text {th }} \mathrm{c} .\end{array}$ \\
\hline Terrace & Ez I & Ez II & Ez I & Ez III & Ez III & Ez I & Ez IV & Ez I \\
\hline Hordeum vulgare & 3.64 & 1.09 & 0.36 & 2.77 & 0.09 & & 4.09 & 0.95 \\
\hline Triticum aestivum/durum & 0.5 & 0.04 & 0.18 & 2.55 & & & 0.34 & 1.23 \\
\hline Triticum turgidum cf. dicoccon & & 0.32 & & 0.05 & & 0.09 & 0.30 & 0.14 \\
\hline Cerealia & 6.36 & 2.18 & 0.73 & 14.77 & 0.18 & 0.41 & 6.36 & 1.41 \\
\hline Cicer arietinum & & & & 0.23 & & & 0.91 & \\
\hline Lens culinaris & 0.68 & & 0.09 & 0.18 & 0.14 & & 1.05 & 0.09 \\
\hline Pisum sativum & 0.04 & & 0.05 & & & & 0.36 & 0.05 \\
\hline Vicia ervilia & 0.14 & & & & 0.05 & & 0.23 & \\
\hline Vicia cf. $f a b a$ & & & & 0.05 & & & 0.05 & \\
\hline Vicia cf. sativa & & & & & & & 0.14 & \\
\hline Fabaceae & 0.27 & 1.14 & 0.45 & 3.23 & & & 8.14 & 0.18 \\
\hline Ficus cf. carica & 0.27 & 0.36 & 0.14 & 1.68 & 0.45 & 0.41 & 16.55 & 0.05 \\
\hline Juglans regia & & & & & & & 0.14 & \\
\hline Olea europaea & 0.68 & 0.33 & 1.34 & 6.90 & 3.59 & 11.40 & 6.14 & 1.36 \\
\hline Phoenix dactylifera & 0.27 & 0.04 & 0.09 & 0.18 & & & 0.23 & 0.05 \\
\hline Prunus armeniaca & & & & & & & 0.05 & \\
\hline Prunus persica & & & & & & & 0.09 & \\
\hline Vitis vinifera & 0.26 & 0.19 & 0.27 & 45.86 & 0.18 & 0.26 & 2.44 & 0.14 \\
\hline Wild/weed plants & 0.23 & 0.5 & 0.23 & 11.14 & 0.41 & 0.23 & 46.23 & 0.14 \\
\hline
\end{tabular}


Table 4. Distribution of the wild species found in Ez III during the Nabataean period (Nab) and Ez IV during the Late Roman period (LRom) according to modern weed plant communities and lifecycle (Zohary, 1973). $\mathrm{a}=$ annual, $\mathrm{b}=$ biannual, $\mathrm{p}=$ perennial. The doubtful taxa (cf.) are excluded.

\begin{tabular}{|c|c|c|c|c|c|c|}
\hline Taxa & $\begin{array}{c}\mathrm{Ez} \text { III } \\
\mathrm{Nab}\end{array}$ & $\begin{array}{l}\text { Ez IV } \\
\text { LRom }\end{array}$ & $\begin{array}{c}\text { Secalinetea } \\
\text { orientalia }\end{array}$ & $\begin{array}{c}\text { Panicetea } \\
\text { hydro-segetalia }\end{array}$ & Ruderals & $\begin{array}{c}\text { Biological } \\
\text { lifecycle }\end{array}$ \\
\hline Silene sp. & & & + & & + & $\mathrm{a}, \mathrm{p}$ \\
\hline Asperula/Galium & & & + & & + & $\mathrm{a}, \mathrm{p}$ \\
\hline Melilotus/Trifolium & & & + & & + & $\mathrm{a}, \mathrm{p}$ \\
\hline Medicago sp. & & & + & & + & $a, b, p$ \\
\hline Fumaria sp. & & & + & & & $\mathrm{a}$ \\
\hline Panicum/Setaria & & & + & + & + & $\mathrm{a}, \mathrm{p}$ \\
\hline Erodium $\mathrm{sp}$. & & & & & + & $\mathrm{a}, \mathrm{p}$ \\
\hline Malva sp. & & & & & + & $\mathrm{a}, \mathrm{p}$ \\
\hline Plantago cf. lanceolata & & & & & + & $\mathrm{p}$ \\
\hline Astragalus/Trigonella & & & + & & + & $\mathrm{a}, \mathrm{b}$ \\
\hline Buplerum sp. & & & + & & + & $\mathrm{a}$ \\
\hline Cerastium sp. & & & + & & & $\mathrm{a}$ \\
\hline Coronilla sp. & & & + & & & $\mathrm{a}$ \\
\hline Hordeum cf. spontaneum & & & + & & + & $\mathrm{a}$ \\
\hline Lolium temulentum & & & + & & & $\mathrm{a}$ \\
\hline Papaver sp. & & & + & & + & $\mathrm{a}$ \\
\hline Viola sp. & & & + & & & $\mathrm{a}$ \\
\hline $\begin{array}{l}\text { Amaranthus/ } \\
\text { Chenopodium }\end{array}$ & & & + & + & + & a \\
\hline Lolium sp. & & & + & & + & $\mathrm{a}$ \\
\hline Malva cf. parviflora & & & & & + & $\mathrm{a}$ \\
\hline Androsace sp. & & & + & & & $\mathrm{a}$ \\
\hline Euphorbia cf. aleppica & & & + & & & $\mathrm{a}$ \\
\hline Heliotropium sp. & & & + & + & + & $\mathrm{a}, \mathrm{p}$ \\
\hline Phalaris sp. & & & + & & + & $\mathrm{a}$ \\
\hline Polygonum/Rumex & & & + & & + & $\mathrm{a}, \mathrm{p}$ \\
\hline Onopordum sp. & & & + & & + & $\mathrm{p}$ \\
\hline
\end{tabular}


Table 5. Anthracological results of ez-Zantur, Petra. ENab= Early Nabataean, Nab=Classical Nabataean, LRom=Late Roman. NR= Number of remains, Ub=Ubiquity, C.I.= precision of the Confidence Interval (95\%)

\begin{tabular}{|c|c|c|c|c|c|c|c|c|c|c|c|c|}
\hline & \multicolumn{4}{|c|}{ ENab } & \multicolumn{4}{|c|}{$\mathrm{Nab}$} & \multirow{2}{*}{\multicolumn{4}{|c|}{$\begin{array}{l}\text { LRom } \\
\text { Ez IV }\end{array}$}} \\
\hline & \multicolumn{2}{|c|}{ Ez I } & \multicolumn{2}{|c|}{ Ez II } & \multicolumn{2}{|c|}{ Ez I } & \multicolumn{2}{|c|}{ Ez III } & & & & \\
\hline Number of samples & \multicolumn{2}{|c|}{5} & \multicolumn{2}{|c|}{5} & \multicolumn{2}{|c|}{6} & \multicolumn{2}{|c|}{3} & \multicolumn{4}{|c|}{15} \\
\hline \multirow[t]{2}{*}{ Volume (1) } & \multicolumn{2}{|c|}{22} & \multicolumn{2}{|c|}{21.6} & \multicolumn{2}{|c|}{23.4} & \multicolumn{2}{|c|}{5.4} & \multicolumn{4}{|c|}{208.1} \\
\hline & NR & $\mathrm{Ub}$ & NR & $\mathrm{Ub}$ & NR & $\mathrm{Ub}$ & NR & $\mathrm{Ub}$ & NR & $\%$ & C.I. & $\mathrm{Ub}$ \\
\hline \multicolumn{13}{|l|}{ Cultivated fruit trees } \\
\hline Ficus cf. carica & - & - & - & - & 10 & 1 & - & - & - & - & & - \\
\hline Olea europaea & 2 & 1 & - & - & 1 & 1 & 1 & 1 & 180 & $41 \%$ & 4.6 & 10 \\
\hline Vitis vinifera & - & - & - & - & - & - & - & - & 11 & $3 \%$ & 1.6 & 2 \\
\hline \multicolumn{13}{|l|}{ Desert plants } \\
\hline Acacia sp. & 2 & 2 & 4 & 2 & 52 & 1 & - & - & 75 & $17 \%$ & 3.5 & 5 \\
\hline Amaranthaceae & 1 & 1 & 1 & 1 & 4 & 2 & 10 & 2 & 8 & $2 \%$ & 1.3 & 2 \\
\hline \multicolumn{13}{|l|}{ Open forest } \\
\hline Cistus sp. & - & - & - & - & - & - & - & - & 6 & $1 \%$ & 0.9 & 1 \\
\hline Cupressus sempervirens & - & - & - & - & - & - & - & - & 10 & $2 \%$ & 1.3 & 1 \\
\hline Cupressus/Juniperus & - & - & - & - & - & - & - & - & 9 & $2 \%$ & 1.3 & 2 \\
\hline Fabaceae & 2 & 1 & 1 & 1 & 8 & 3 & 28 & 2 & 30 & $7 \%$ & 2.4 & 3 \\
\hline Juniperus sp. & - & - & 1 & 1 & 6 & 2 & - & - & 10 & $2 \%$ & 1.3 & 5 \\
\hline Pinus sp. & - & - & - & - & - & - & - & - & 5 & $1 \%$ & 0.9 & 1 \\
\hline Pistacia $\mathrm{sp}$. & 12 & 5 & 11 & 4 & 8 & 2 & - & - & 48 & $11 \%$ & 2.9 & 5 \\
\hline cf. Prunus sp. (ring-porous) & - & - & - & - & - & - & - & - & 2 & $0.5 \%$ & 0.7 & 2 \\
\hline Qercus calliprinos type & 2 & 1 & 2 & 1 & 3 & 1 & 1 & 1 & 3 & $0.5 \%$ & 0.7 & 1 \\
\hline Quercus ithaburensis type & - & - & - & - & - & - & - & - & 5 & $1 \%$ & 0.9 & 1 \\
\hline Rhamnus sp. & - & - & - & - & 1 & 1 & - & - & 6 & $1 \%$ & 0.9 & 2 \\
\hline \multicolumn{13}{|l|}{ Riparian gallery } \\
\hline Platanus orientalis & - & - & - & - & - & - & - & - & 5 & $1 \%$ & 0.9 & 1 \\
\hline Salix sp. & - & - & - & - & - & - & - & - & 10 & $2 \%$ & 1.3 & 2 \\
\hline Tamarix sp. & - & - & 2 & 1 & 8 & 1 & 1 & 1 & 9 & $2 \%$ & 1.3 & 3 \\
\hline Indeterminate & - & - & - & - & - & - & - & - & 7 & $2 \%$ & 1.3 & 2 \\
\hline Sum & 21 & & 22 & & 101 & & 41 & & 439 & & & \\
\hline
\end{tabular}

Table 6. Taxa identified through carpological and wood charcoal analyses. ENab= Early Nabataean, $\mathrm{Nab}=$ Nabataean, LRom=Late Roman, $\mathrm{c}=$ carpological results, $\mathrm{a}=$ anthracological results.

\begin{tabular}{|c|c|c|c|c|c|c|c|c|}
\hline Taxa & \multicolumn{2}{|c|}{ ENab } & \multicolumn{2}{|c|}{$\mathrm{Nab}$} & \multirow{2}{*}{$\frac{\text { Rom }}{\mathrm{c}}$} & \multicolumn{2}{|c|}{ LRom } & \multirow{2}{*}{$\frac{\mathrm{Byz}}{\mathrm{c}}$} \\
\hline & $\mathrm{c}$ & $\mathrm{a}$ & $\mathrm{c}$ & $\mathrm{a}$ & & $\mathrm{c}$ & $\mathrm{a}$ & \\
\hline \multicolumn{9}{|c|}{ Cultivated fruit trees } \\
\hline Ficus cf. carica & + & & + & + & & + & & + \\
\hline Olea europaea & + & + & + & + & & + & + & + \\
\hline Vitis vinifera & + & & + & & & + & + & + \\
\hline \multicolumn{9}{|c|}{ Wild shrubs and trees } \\
\hline Acacia $\mathrm{sp}$ & & + & & + & & & + & + \\
\hline Amaranthaceae & & + & + & + & & + & + & \\
\hline Pistacia sp. & + & + & + & + & & & + & \\
\hline
\end{tabular}


Table 7. Distribution of the main cultivated species in several archaeological sites of the Southern Middle East according to the estimation of the minimum number of plant macro-remains proportions recovered (from $\mathrm{x}=$ present to $\mathrm{xxx}=$ abundant, $+=$ no available quantitative data)

\begin{tabular}{|c|c|c|c|c|c|c|c|c|c|c|}
\hline & \multicolumn{5}{|c|}{ Petra garden\&Pool complex (PGPC) } & \multicolumn{2}{|c|}{ Obodas Chapel } & \multirow{2}{*}{$\begin{array}{c}\begin{array}{c}\text { Ath- } \\
\text { Thughrah }\end{array} \\
4^{\text {th }} \text { c. BC- } 4^{\text {th }} \\
\text { c. AD }\end{array}$} & \multirow{2}{*}{$\begin{array}{c}\text { Udruh } \\
2^{\text {nd }}-3^{\text {rd }} c . A D\end{array}$} & \multirow{2}{*}{$\begin{array}{l}\text { Bir madkhur } \\
4^{\text {th }}-6^{\text {th }} \text { c. AD }\end{array}$} \\
\hline & $\begin{array}{c}1^{\text {st }} \text { c. BC-early } \\
1^{\text {st }} \text { c. AD }\end{array}$ & $\begin{array}{l}\text { early } 1^{\text {st }} c .- \\
\text { early } 2^{\text {nd }} c .\end{array}$ & $\begin{array}{c}2^{\text {nd }}-3^{\text {rd }} \\
c .\end{array}$ & $\begin{array}{l}1^{\text {st }} \text { half } \\
4^{\text {th }} \mathrm{c} .\end{array}$ & $\begin{array}{c}4^{\text {th }} \text {-early } \\
5^{\text {th }} c .\end{array}$ & $\begin{array}{c}2^{\text {nd }}-1^{\text {st }} c . \\
B C\end{array}$ & $\begin{array}{c}1^{\text {st }}-2^{\text {nd }} c . \\
A D\end{array}$ & & & \\
\hline Cereals & & & & & & & & & & $\mathrm{xx}$ \\
\hline Hordeum vulgare & & $\mathrm{x}$ & $\mathrm{x}$ & $\mathrm{x}$ & $\mathrm{x}$ & $\mathrm{x}$ & & $\mathrm{x}$ & + & + \\
\hline Triticum aestivum/durum & & & $\mathrm{x}$ & $\mathrm{x}$ & $\mathrm{x}$ & & & & & + \\
\hline T.aestivum ssp. compactum & & & & & & & & & & + \\
\hline T.turgidum subsp. durum & & & & & & & & & & + \\
\hline T.turgidum ssp. dicoccum & & & & & & & & & + & + \\
\hline Cerealia & $\mathrm{xx}$ & $\mathrm{x}$ & $\mathrm{x}$ & $\mathrm{x}$ & $\mathrm{xx}$ & $\mathrm{xxx}$ & $\mathrm{xx}$ & $\mathrm{xX}$ & & + \\
\hline Pulses & & & & & & & & & & $\mathrm{x}$ \\
\hline Cicer arietinum & & & $\mathrm{x}$ & & & & & & & \\
\hline Lathyrus sp. & & $\mathrm{x}$ & $\mathrm{x}$ & & & & & & & \\
\hline Lens culinaris & $\mathrm{x}$ & $\mathrm{x}$ & $\mathrm{x}$ & & & & & $\mathrm{xx}$ & & + \\
\hline Pisum sativum & & & & & & $\mathrm{x}$ & & & & + \\
\hline Vicia ervilia & & & $\mathrm{x}$ & & & & & & & \\
\hline Vicia cf. faba & & & & & & & & & & + \\
\hline Vicia cf. sativa & & & & & & & & & & + \\
\hline Fruit trees & & & & & & & & & & $\mathrm{x}$ \\
\hline Ficus cf. carica & $\mathrm{xx}$ & $\mathrm{x}$ & $\mathrm{xx}$ & $\mathrm{x}$ & $\mathrm{xx}$ & $\mathrm{x}$ & $\mathrm{xx}$ & $\mathrm{x}$ & + & + \\
\hline Olea europaea & $\mathrm{xx}$ & $\mathrm{xxx}$ & $\mathrm{xx}$ & $\mathrm{xxx}$ & $\mathrm{xxx}$ & & $\mathrm{x}$ & $\mathrm{x}$ & + & + \\
\hline Phoenix dactylifera & & $\mathrm{x}$ & $\mathrm{x}$ & $\mathrm{x}$ & $\mathrm{x}$ & & & $\mathrm{x}$ & & + \\
\hline Vitis vinifera & $\mathrm{xx}$ & $\mathrm{Xx}$ & $\mathrm{xx}$ & $\mathrm{xx}$ & $\mathrm{xxx}$ & $\mathrm{x}$ & $\mathrm{xxx}$ & & & + \\
\hline References & & Ramsay and & edal 20 & & & $\begin{array}{r}\text { Bouchau } \\
\text { Tholbec } \\
20\end{array}$ & $\begin{array}{l}2011, \\
\text { eq et al. } \\
08\end{array}$ & $\begin{array}{c}\text { Sachet et al. } \\
2013\end{array}$ & Neef 1987,1990 & Ramsay and Smith 2013 \\
\hline
\end{tabular}

